\title{
Plant Protection by Benzoxazinoids-Recent Insights into Biosynthesis and Function
}

\author{
Claudiu Niculaes, Aleksej Abramov, Laura Hannemann and Monika Frey * \\ Chair of Plant Breeding, TUM School of Life Sciences Weihenstephan, Technical University of Munich, \\ 85354 Freising, Germany; claudiu.niculaes@tum.de (C.N.); aleksej.abramov@tum.de (A.A.); \\ laura.hannemann@tum.de (L.H.) \\ * Correspondence: monika.frey@tum.de; Tel.: +49-8161-71-5642
}

Received: 13 July 2018; Accepted: 9 August 2018; Published: 11 August 2018

\begin{abstract}
Benzoxazinoids (BXs) are secondary metabolites present in many Poaceae including the major crops maize, wheat, and rye. In contrast to other potentially toxic secondary metabolites, BXs have not been targets of counter selection during breeding and the effect of BXs on insects, microbes, and neighbouring plants has been recognised. A broad knowledge about the mode of action and metabolisation in target organisms including herbivorous insects, aphids, and plants has been gathered in the last decades. BX biosynthesis has been elucidated on a molecular level in crop cereals. Recent advances, mainly made by investigations in maize, uncovered a significant diversity in the composition of BXs within one species. The pattern can be specific for single plant lines and dynamic changes triggered by biotic and abiotic stresses were observed. Single BXs might be toxic, repelling, attractive, and even growth-promoting for insects, depending on the particular species. BXs delivered into the soil influence plant and microbial communities. Furthermore, BXs can possibly be used as signalling molecules within the plant. In this review we intend to give an overview of the current data on the biosynthesis, structure, and function of BXs, beyond their characterisation as mere phytotoxins.
\end{abstract}

Keywords: benzoxazinoids; structural diversity; defence; herbivory; allelopathy; plant-microbe interaction; detoxification

\section{Introduction}

A unique feature of plants is the biosynthesis of secondary metabolites, also termed specialised metabolites [1]. The number of secondary metabolites in the plant kingdom is estimated at about 200,000 [2]. Although not essential for the survival of the individual plant, secondary metabolites are vital for "communication" within the bio-system including attraction, repelling, and defence reactions. The concept underlying the functionality of secondary metabolites is diversity and reactivity. Families of secondary metabolites can occur in certain plant taxa and can then be used for taxonomy [3], but some metabolites also have scattered appearance. Secondary metabolites are often unstable and react with other compounds, thereby generating toxicity, which qualifies them as natural defence compounds. The multitude of compounds active in defence limits the emergence of generalist deleterious insects and pathogenic microbes.

During the breeding of crop plants, the inherent toxicity has led to the reduction of secondary metabolites. Well known examples of counter selection are given by the quinolizidine alkaloids present in lupines and alkaloids in tubers of potatoes (see [3] for review). Benzoxazinoids (BXs) are well-known secondary metabolites found in cereal crops and, in contrast to the cases of counter selection, benzoxazinoids have been targets of positive selection in breeding for maize tolerance to insects since the 1970s [4-6]. The untargeted reactivity implies autotoxicity that has to be circumvented 
by the producing plant. In the so-called two-component defence systems, reactivity is reduced by chemical modification, mostly glycosylation, and simultaneously a reactivating enzyme, e.g., a glycosidase, is provided. The stabilised metabolite (component one) and activating enzyme (component two) are physically separated in different organelles or tissues but meet in case of cell damage, thereby liberating the toxin. Examples are alkaloid glucosides, benzoxazinoid glucosides, cyanogenic glucosides, glucosinolates, iridoid glucosides, and salicinoids (see [7] for review).

Advances in chemical analysis and well-developed genetic resources, especially in maize, have revealed distinct functions for different BXs in defence. Furthermore, in planta signalling is a matter of debate [8]. Within maize populations, diversity in the quality and quantity of different BXs has been revealed. Recent reviews summarise the role of BXs on plant-plant allelopathy [9], deal with the interaction between BXs and insects [10], and describe the BX structure diversity and function in maize [8]. Here we aim to give an overview on the present knowledge of the biosynthesis, distribution, and biological function of different BXs. The available data on BX-mediated interactions are summarised in Table 1, providing a guide through the literature.

\section{Structure of Benzoxazinoids and Chemical Properties}

BXs comprise two classes, benzoxazolinones (1,3-benzoxazol-2-one, e.g., 6-methoxy-2benzoxazolinone (MBOA) in Figure 1) and benzoxazinones (1,4-benzoxazin-3-one, e.g., 2,4dihydroxy-1,4-benzoxazin-3-one (DIBOA), 2,4-dihydroxy-7-methoxy-1,4-benzoxazin-3-one (DIMBOA), 2-hydroxy-4,7-dimethoxy-1,4-benzoxazin-3-one (HDMBOA), 2-hydroxy-4,7,8-trimethoxy1,4-benzoxazin-3-one ( $\left.\mathrm{HDM}_{2} \mathrm{BOA}\right)$ in Figure 1$)$, with several subclasses each. In plants, $N$-hydroxyl benzoxazinones are predominant. Decoration by hydroxyl- and methoxy- groups at positions C-7 and C-8 and the additional methylation of the $N$-hydroxyl are the most common modifications found for benzoxazinones (Figure 1). While the 2-OH glucosides (GDIBOA, GDIMBOA, etc.) are quite stable [11], the aglucons have significant reactivity. Both the $\mathrm{N}-\mathrm{OH}$ function and the cyclic hemiacetal unit are largely essential for the reactivity. The hemiacetal undergoes an oxo-cyclo-tautomerisation. In the oxo form, the aldehyde group is free to react with the epsilon- $\mathrm{NH}_{2}$ group of the $\mathrm{N}$-alpha-acetyl-Lys. $\mathrm{N}$-alpha-acetyl-L-lysine is a lysine analogue used as a model substrate to demonstrate the targeting of Lys residues and general nucleophilic residues in proteins. [12]. The resistance of maize towards the herbicide atrazine is attributed to nucleophilic attack by DIMBOA [13,14].

Comparing the major benzoxazinoids DIBOA and DIMBOA, the latter is definitely more reactive. The 7-MeO group of DIMBOA facilitates N-O bond heterolysis as a donor [15] and the dehydration of DIMBOA [16]. In this way, a multicentered cationic electrophile and a reactive formyl donor toward $-\mathrm{NH}_{2},-\mathrm{OH}$, and $-\mathrm{SH}$ groups are generated. Reactivity towards thiols potentially interferes with enzyme function if the cysteine residues in proteins are affected; furthermore, glutathione (GSH) can be targeted. The resulting formation of stable thioether conjugates leads to the rapid depletion of GSH levels [17]. In addition, the heterocycle of the benzoxazinone can assume ring-opened conformation after oxo-cyclo-tautomerisation and spontaneous transformation into the respective benzoxazolinone takes place. Since the half-life time of HDMBOA in watery solution is 10 times shorter than that of DIMBOA [18] and the generation of the reactive MBOA is accordingly more rapid, GHDMBOA might be the fastest activated BX for defence.

Among the defined molecular interactions of benzoxazinones that disturb cell function are the inhibition of alpha-chymotrypsin [19], cholinesterase [20], and plasma membrane $\mathrm{H}^{+}$-ATPase [21]. Furthermore, BXs intercalate with nucleic acids [15] and might cause mutations. However, BXs are not super toxins; effective defence requires concentrations in the millimolar range and acute mortality is not caused.

\section{Distribution of Benzoxazinoids}

Characteristically, benzoxazinoids are found in wild and cultivated Poaceae [22,23]. Besides that, BXs have been detected in distant orders of eudicots, in the family Ranunculales, and in the Lamiales 
families Acanthaceae, Plantaginaceae, and Lamiaceae. While just one species each of the families Ranunculaceae (Consolida orientalis Schrödinger), Plantaginaceae (Scoparia dulcis L.), Lamiaceae (Lamium galeobdolon (L.) L.), and Calceolariaceae (Calceolaria thyrsiflora Graham) synthesise BXs, several Acanthaceae species do so [22,23]. Within the family Poaceae, BX presence has been shown for the perennial bunchgrass Chrysopogon zizanioides (L.) Roberty as well as the aggressive perennial grass Agropyron repens (L.) P.Beauv. Most importantly, BXs are found in the crops Zea mays L. and the wild progenitor Teosinte, Triticum aestivum L., and diploid wheat species, Secale cereale L., as well as some wild Hordeum species (Hordeum roshevitzii Bowden, Hordeum brachyantherum Phil., Hordeum flexuosum Steud., Hordeum lechleri Steud.).

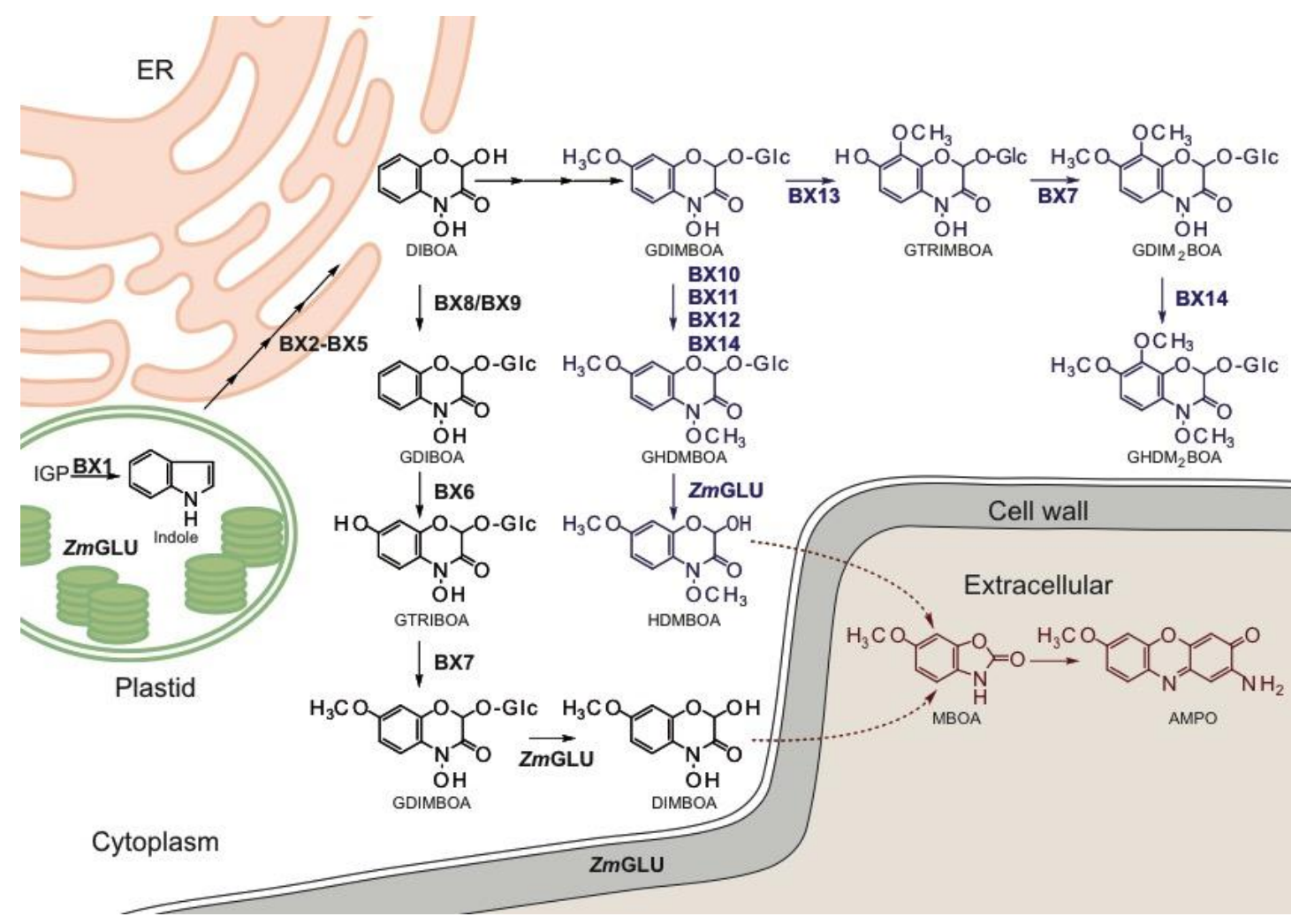

Figure 1. Biosynthesis of benzoxazinoids (BXs) as determined for maize. Compounds and enzymes of the core pathway are depicted in black. Depending on developmental stages and biotic interactions, modifications of BXs are induced. The resulting compounds and the employed enzymes of the inducible branches are coloured in blue. The enzymes locate to the plastid (BX1), to the endoplasmic reticulum membrane (BX2 to BX5), and to the cytosol (BX8 and BX9, $B X 6, B X 7$, and BX10 to BX14). The glucosides might be stored in the vacuole and hence are protected against the specific glucosidase, which is found in the plastid and associated with the cell wall. When the cell is disrupted, the glucosides come in contact with the glucosidase and the aglucons are generated. 2,4-dihydroxy-7-methoxy-1,4-benzoxazin-3-one (DIMBOA) and 2-hydroxy-4,7-dimethoxy-1,4-benzoxazin-3-one (HDMBOA) are unstable and the degradation product 6-methoxy-2-benzoxazolinone (MBOA) is spontaneously formed in a watery solution (red colour). Enzymatic transformation by microbes, especially in the soil, yields further catabolites, e.g., stable amino-phenoxazinones such as 2-amino-7-methoxy-phenoxazin-3-one (AMPO). Indole-3-glycerol phosphate (IGP). 
In cereal crops, (G)DIMBOA (e.g., maize, wheat) and (G)DIBOA (wild Hordeum species) are prevalent in unstressed plants. A distinction in the dominating $B X_{s}$ is found in rye; in aboveground tissue (G)DIBOA dominates, while (G)DIMBOA is prevalent in rye roots. The highest concentrations of BXs are found in seedlings of the family Poaceae.

Maize can be considered as model system for BX analysis in the crop cereals. DIMBOA is detectable shortly after the onset of maize germination and the highest concentrations are found 4 to 11 days after imbibition (10 to $30 \mathrm{mM}$ in the shoot, $0.5-15 \mathrm{mM}$ in the root, [24]). The maximal concentration and the persistence differ for different maize lines. Effective concentrations for defence beyond the seedling stage are restricted to exceptional lines in the Nested Association Mapping (NAM, [25]) diversity panel [24]. In mature maize plants, however, the concentration and modification of BXs can be changed by microbial and herbivore attack (see below). BXs have not been detected in maize seed. By contrast, kernels of wheat and rye contain BXs [26]. While in rye the largest part is located in the bran, wheat also has significant amounts of BXs in the germ [27]. The BXs in seeds are mostly DIBOA- and 2-hydroxy-1,4-benzoxazin-3-one (HBOA)-diglycosides and concentrations reach up to $0.15 \mathrm{nmol}$ in dry matter. Diglycosides are unusual benzoxazinoids and might function as special storage metabolites.

(G)DIBOA is the main BX in dicots, others, e.g., DIMBOA (in Aphelandra sp.), are only present in traces $[22,23,28]$. Peak amounts are not restricted to the seedling stage. On the contrary, juvenile stages of $C$. orientalis have the lowest concentrations. Interestingly, flowers proved to have high BX concentrations while the root might have levels below detection limits [28]. Whether the differences in BX patterns of dicots and monocots reflect different defence strategies is unknown. Data for dicots are rare but antifeeding activity of BXs towards the larvae of the moth Pseudaletia impuncta (Guenée 1852) has been shown for Acanthus mollis L. [29].

\section{Biosynthesis}

BX biosynthetic pathway elucidation was largely done in maize and the biosynthetic steps and $B x$-gene functions were defined in maize. The biosynthesis of the core BXs GDIBOA and GDIMBOA was discovered in maize [30-32] and subsequently in wheat and in part in rye [33-39]. The pathway branches off from tryptophan biosynthesis (Figure 1) by the signature enzyme BX1, which is a homologue of the alpha subunit of tryptophan synthase (TSA). BX1 and TSA share the substrate, indole-3-glycerol phosphate, and the product, indole [30,40]. In contrast to TSA, which requires allosteric activation by the beta-subunit of the tryptophan synthase (TSB) in the hetero-dimeric tryptophan synthase (TS) complex [41], BX1 is active as a monomer and indole is released. In tryptophan biosynthesis, indole remains in the tunnel connecting TSA and TSB and is further metabolised. Free indole delivered by BX1 is converted by four consecutive hydroxylation reactions catalysed by the cytochrome P450 enzymes BX2 to BX5 into the benzoxazinoid DIBOA [30,42]. DIBOA is stabilised by glucosylation by either of the two UDP-glucosyltransferases (UGT) BX8 and BX9 [31]. Hydroxylation of GDIBOA is by the 2-oxoglutarate dependent dioxygenase (ODD) BX6. Methylation of the resulting 2,4,7-trihydroxy-8-methoxy-1,4-benzoxazin-3-one-O-glucoside (GTRIMBOA) by the O-methyltransferase (OMT) BX7 completes GDIMBOA biosynthesis [32].

The ratio and kind of modification of the basic BXs depends on developmental stages, abiotic and biotic stress, and genotypes (see [23] for review). The levels at the seedling stage are quite stable, while mature plants respond to different challenges with changes in $B X$ amounts and patterns (e.g., [43]). In planta GDIMBOA can be hydroxylated by the OMTs BX10, BX11, and BX12 to yield GHDMBOA (Figure 1, [44]). While the expression of $B \times 12$ is constitutive, Bx10 and Bx11 are induced by herbivory (Spodoptera exigua (Hübner 1808), [45]). $\mathrm{BX} 13$, an ODD homologous to BX6, and a further OMT, BX14, are required for the synthesis of 2,4-dihydroxy-7,8-dimethoxy-1,4-benzoxazin-3-one-O-glucoside $\left(\mathrm{GDIM}_{2} \mathrm{BOA}\right)$ and $\mathrm{GHDM}_{2} \mathrm{BOA}$ (Figure 1, [46]). BX14 and BX10 to BX12 share the in vitro function as GDIMBOA methyltransferases to yield GHDMBOA, but BX14 is distinguished by its activity towards $\mathrm{DIM}_{2} \mathrm{BOA}$ and is required for 
the biosynthesis of $\mathrm{GHDM}_{2} \mathrm{BOA}$ [46]. Enzymes of BX biosynthesis locate to different intracellular compartments. $\mathrm{BX} 1$ is found in the stroma of the plastid [47], BX2 to BX5 are anchored in the endoplasmic reticulum membrane, the ODDs (BX6, BX13) and the OMTs (BX7, BX10, BX11, BX12, $\mathrm{BX} 14)$ are soluble cytosolic enzymes. BX-glucosides are stored in the vacuole.

The core genes $B x 1$ to $B x 5$ and $B x 8$ form a biosynthetic cluster in maize and locate within $264 \mathrm{~kb}$ on the short arm of chromosome 4 . A distant enhancer element for $B x 1$ expression is situated in the middle of the cluster $[24,48]$. The first intermediate unique to BX biosynthesis is indolin-2-one, generated by BX2. Phylogenetic data suggest the co-evolution of $B \times 1$ and $B \times 2$ to be an essential driver in the establishment of the pathway. Indeed, both genes are extremely tightly linked in maize (separated by $2.5 \mathrm{~kb},[30])$ and the linkage is preserved in wheat and rye while the second part of the cluster, $B \times 3$ to $B \times 5, B x 8$, is found on different chromosomes [36,37]. The essential impact of BX1 for benzoxazinoid biosynthesis has been shown by transgenic overexpression in maize [24] and by QTL (quantitative trait locus) analysis [49]. $B x 6$ and $B x 7$ are also found on the short arm of chromosome 4 , but are separated from the core cluster by several centimorgans. The genes involved in the decoration of GDIMBOA are not linked to the core gene set. $B x 10$ to $B x 12$ most probably represent gene duplications and the paralogues are located within $200 \mathrm{~kb}$ on chromosome 1 [44]. Bx13 and Bx14 are both found on chromosome 2 but are distant from each other.

Benzoxazinoid biosynthesis in maize was the first example of a biosynthetic cluster in plants. Since then, they have also been discovered for secondary metabolism in several plant species (reviewed in [50]). Clustering was even used as a criterion to elucidate pathways [51]. However, many biosynthetic pathways are dispersed in the genome [52]. Whether clustering provides an evolutionary advantage for pathway establishment by preserving superior allelic combinations in the coupling phase, or facilitates coordinated regulation through the domains of modified chromatin is a matter of debate. The local separation of the core gene set and the genes of modification might be underlying the diversity of BXs patterns found in maize [44,46,53]. It is suggested that the glucosylated benzoxazinoids are stored in the vacuole. The BX-glucoside specific beta-glucosidases were detected in the plastid and connected to the cell wall [54-57]. The disintegration of cells joins stored glucosidase and substrate and delivers the defence compound.

Recently, signalling components involved in induced BX changes have been discovered. It has been shown that $Z m P E P 1$ and $Z m P E P 3$, members of the maize elicitor peptide family, were rapidly induced by either fungal infection or oral secretions of the Spodoptera exigua larvae [58,59]. In both cases, jasmonate and ethylene biosynthesis and a broad spectrum of defence reactions is induced, including the expression of $B x$-genes. Whether the observed changes in gene expression and $B X$ patterns are direct or indirect consequences of $Z m P E P$ activity is unclear. A significant function might be attributed to the jasmonate (JA) signalling cascade since JA application and JA synthesis inhibition enhanced and constrained, respectively, the concentration of GHDMBOA [60,61].

As mentioned before, most data about BX biosynthesis were gained through analyses of maize. The respective genes in other Poaceae species were found based on homology searches and all genes identified so far are orthologues, hence the BX biosynthetic pathway is monophyletic in Poaceae. The knowledge about the pathway in dicots is scarce. It has been shown that, like in monocots, indole is generated by a homologue of TSA and further metabolised to yield BXs. However, the $B x 1$ genes of the family Poaceae and the dicots A. squarrosa, C. orientalis, and L. galeobdolon are results of individual convergent evolution [28]. Similarly, the UGT gene CoBx8 and the specific glucosidases CoGlu and LgGlu1 from C. orientalis and L. galeobdolon are the result of repeated evolution [62,63]. It cannot be excluded that a loss of genes and secondary recruitment took place, but most likely BX biosynthesis evolved several times independently.

\section{Biological Interaction}

Different techniques were applied to study the biological impact of BXs. Pure substances were applied in solution (e.g., in Sections 5.1-5.3 and 5.5), added to artificial diets, or applied through 
the painting of leaves (Section 5.4). Concentrations in the millimolar range might face insects and microbes attacking seedlings. In older plants, such a high concentration can result locally from induced biosynthesis [58,59]. Another line of investigation was to analyse plant lines or cultivars producing BXs at different levels for the effect on target organisms (Sections 5.3 and 5.4). A summary of compoundand species-specific interactions is given in Table 1.

\subsection{Human Health Clinical Studies, Detrimental and Health-Promoting Effects}

Maize seed and silage tissue are lacking significant amounts of BXs, but due to the presence of BX in seeds of wheat and rye, BX can enter the human food chain. BXs have been found in conventionally baked bread and water-soaked or -boiled pearled rye and rye flakes [27]. Furthermore, BXs have been detected in wheat and rye beer [64]. The health-promoting effects of whole grain wheat and rye products have been associated with the presence of BXs. Anti-allergenic and anti-inflammatory effects have been demonstrated, and it was reported that BXs are appetite-suppressing in humans and may reduce cellular glucose uptake (see [65] for review). Hamilton described DIMBOA in 1962 as a "corn sweet substance" [66], as for human taste buds it is about 400 times sweeter than sucrose [8]. This might account for the reduction of calorie uptake by humans consuming BX-supplemented diets. Additionally, BXs might influence the microbial community of the digestive system positively and their health-promoting effects might be the result of differential sensitivities of microbes.

On the other hand, detrimental properties of BXs are well known. In vitro mutagenicity of DIMBOA in the Ames test has been described [67]. More recently BXs were described as potent polyploidy-inducing agents in human-derived cell lines (HepG2 and HeLa), which has raised concern for their potential adverse health effects [68,69]. However, due to the ability of potent BXs to induce cell death, applications in cancer treatment are considered [70].

\subsection{Interactions with Microbes}

Early after the detection of BXs in cereal crops, studies were performed to evaluate the antimicrobial potential of the compounds. The microbe targeted was Pantoea stewartii (Smith 1898) Mergaert et al. 1993, (Xanthomonas stewartii (Smith 1898) Dowson 1939, [71]), a causal agent of Stewart's wilt. Similarly, a bacteriostatic effect of DIMBOA was determined for Erwinia spp. and Agrobacterium tumefaciens (Smith \& Townsend 1907) Conn 1942; growth restriction by MBOA was less pronounced [72,73]. In addition to the restriction of bacteria proliferation, BXs have the capacity to influence microbial communities and are like other plant metabolites implicated in mutualistic interactions (see [74] for review). Pseudomonas putida Trevisan, 1889 KT2440, a competitive coloniser of the maize rhizosphere with plant-beneficial traits, is attracted by DIMBOA [75]. Root colonisation by the strain was shown to prime the emission of stress-inducible aromatic and terpenoid volatiles from shoots and the expression of the JA-inducible serine proteinase inhibitor SerPIN. SerPIN priming was shown to require the presence of BX. The underlying mechanism is at present unknown [76].

Local changes of BXs are caused by phytopathogenic fungi (Bipolaris maydis (Y. Nisik. \& C. Miyake) Shoemaker, Curvularia lunata R.R. Nelson \& Haasis, and Alternaria alternata (Fr.) Keissl. (Fr.)) and influence the germination of conidia negatively [43]. A significant accumulation of HDMBOA and thereafter of MBOA was induced by the inoculation of the fungi. The most significant antifungal potential was attributed to MBOA. For cereals, interaction with endophytic Fusarium species is of special interest due to yield loss and contamination with fungal toxins. BXs were first described as anti-Fusarium factors in rye seedlings (benzoxazolinones, [77]; benzoxazinones, [11]). The impact of benzoxazinones and the benzoxazolinones MBOA and 1,3-benzoxazol-2-one (BOA) arising as degradation products on Fusarium infection has been verified repeatedly (e.g., [78]) It has been shown that the biosynthesis of toxic trichothecenes by Fusarium graminearum Schwabe is almost completely abolished by DIMBOA in wheat. The effect is attributed to the suppression of the fungal genes of the trichothecenes biosynthetic pathway [79]. However, Fusarium spp. gained tolerance to BXs multiple times [80]. Tolerance was achieved by the inducible production of modifying enzymes (FDB1, FDB2, 
Fusarium verticillioides (Sacc.) Nirenberg, Fusarium pseudograminearum Aoki and O'Donnell, [81,82]). The F. verticillioides gene FUG1 is required for successful maize kernel colonisation. FUG1 shows features of transcription factors and activates the biosynthesis of fumonisins, a class of mycotoxins. At the same time, FUG1 is required for BX tolerance, though the specific tolerance mechanism is unknown [83]. The presence of BX-tolerant fungi has a major impact on the microbial population structure. The microbial community proportion with low BOA tolerance was significantly reduced (up to 35-fold lower frequency in leaf isolates) in maize BX producer lines [84]. Given the positive correlation between BX tolerance and mycotoxin biosynthesis, the selective advantage of tolerant Fusarium strains when facing high BX concentrations might increase toxin levels of BX-producing cereals. Hence, the presence of BXs might be advantageous or deleterious for the reduction of Fusarium infection and mycotoxin contamination.

BXs were also analysed for antimicrobial properties against the model organisms for human pathogens Escherichia coli (Migula 1895) Castellani \& Chalmers 1919, Staphylococcus aureus Rosenbach, 1884, and Candida albicans (C.P.Robin) Berkhout, as well as the yeast Saccharomyces cerevisiae Meyen ex E.C. Hansen [85-87]. Antimicrobial activity required concentrations above the millimolar range.

\subsection{Benzoxazinoids in the Soil: Allelopathy and the Chelating of Metals}

BXs are found in the soil when BX-producing plants are grown and initially BXs received much attention as allelopathic substances in plant-plant interactions (see [9] for review). The release of BXs follows two modes, root exudation by the vital plant and the shedding of dead tissue. The level of root exudation varies for different species and within species for lines and cultivars. The presence of BXs in the apoplast has been demonstrated in maize [88], but the mechanism of root exudation is unknown. We assessed BXs exudation in young maize seedlings using a system that allowed exudate collection without damaging the root tissue (Figure 2) [89]. Staining revealed the presence of BXs above the root cap (Figure 2A). Collecting exudates separately from the root cap border cells as opposed to the whole root confirmed that the root cap border cells do not play a major role in BXs exudation (Figure 2B). This was somewhat unexpected since the root cap is known to be involved in the exudation of other defence compounds, such as pisatin in pea [90]. Preliminary data using specific inhibitors suggested that exudation takes place passively rather than by primary or secondary active membrane transporters such as the ATP-binding cassette (ABC) transporters and MATE (multidrug and toxic compound extrusion) transporters (Figure 2C,D) [89].

In maize benzoxazinoid content is high in seedling roots, in young adventitious roots, and in crown roots [91,92]. In agricultural practice, the effect of BXs is exploited by mulching and the allelopathic potential has been extensively studied in rye. Experiments with the mulching of rye demonstrated a substantial reduction of weeds, e.g., a reduction of Chenopodium album L. greater than $90 \%$ was detected [93]. BX levels between 0.5 and $5 \mathrm{~kg} /$ ha were reached with field-grown rye. The effects of intact plants on weed control proved to be cultivar-specific and correlated with BX content [94]. Hence, it was postulated that BXs might be used as lead structures for the design of herbicides. Benzoxazinone aglucons are unstable in watery solutions [95], e.g., the half-life values of DIMBOA are between $7 \mathrm{~h}$ and $20 \mathrm{~h}$ depending on $\mathrm{pH}$. The benzoxazolinones $\mathrm{BOA}$ and $\mathrm{MBOA}$ are quite stable under sterile conditions but are converted via aminophenol as an intermediate by microbes to yield either of the catabolite classes aminophenoxazinone, malonamic acids, or acetamides within days [9,96]. Aminophenoxazinones (2-amino-phenoxazin-3-one (APO), 2-amino-7-methoxy-phenoxazin-3-one (AMPO), Figure 1) are persistent in the soil with half-life values of several months [97]. The precursors DIBOA and DIMBOA and (more substantially) the degradation products APO and AMPO have been detected in the roots and shoots of target plants [98]. Hence, the allelopathic potential in the soil depends on both the BXs and, maybe even to a higher extent, on the catabolites. The selectivity in plant communities is given by differences in the uptake and metabolisation of the chemicals. Generally, cereals are more tolerant than dicots, although even maize cells are affected by DIMBOA [99]. Different detoxification pathways are established in different 
plant species $[9,100]$. Considerable changes in the transcriptome of Arabidopsis thaliana (L.) Heynh. seedlings by exposure to BOA might reflect the activation of detoxification reactions. The functional categories 'cell rescue' and 'defence' were overrepresented after BOA treatment [100]. One common mechanism to reduce toxicity is the glucosylation of intermediates. Indeed, the transgenic expression of the respective UGTs BX8 or BX9 conferred DI(M)BOA tolerance to Arabidopsis [31]. The major detoxification product of BOA in Poales was identified as glucoside carbamate and the biosynthetic steps were defined recently in maize roots [101,102]. Thereby, it has been shown that BX9 is also effective in BOA metabolism.

(a)

BXs localization

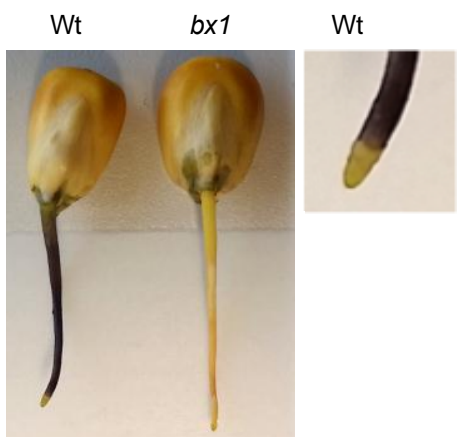

(c)

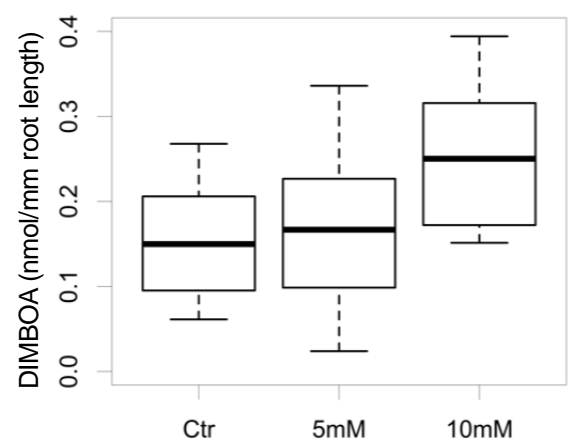

(b) DIMBOA exudation

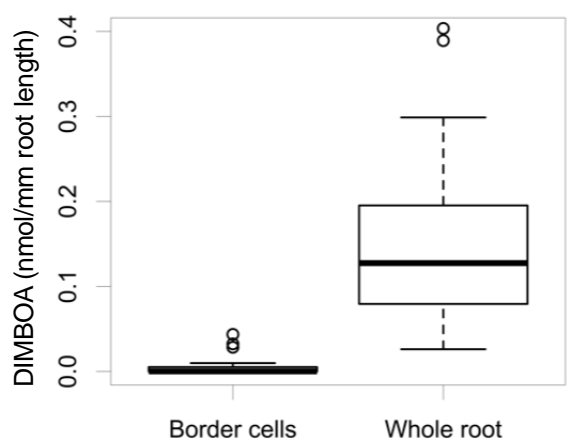

(d) $\quad \mathrm{NH}_{4} \mathrm{Cl}$ treatment

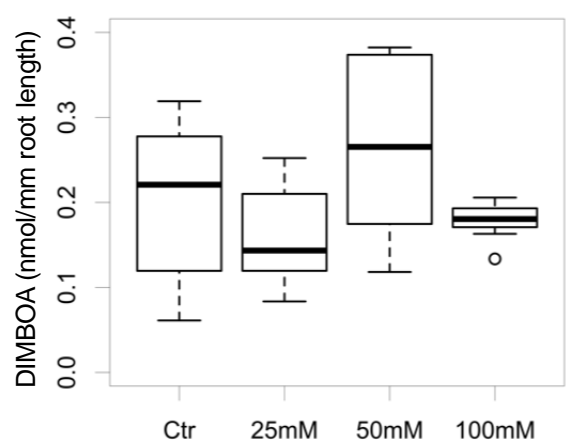

Figure 2. BXs exudation in young maize seedlings. (a) Detection of BXs by staining with $\mathrm{FeCl}_{3}$. BXs form a blue-coloured complex with Fe (III). The benzoxazinless (bx1) mutant root does not show any staining while the wildtype (WT) root is stained, except for the root cap, suggesting that the root cap is not involved in BXs biosynthesis and exudation. (b) DIMBOA amounts in exudate of the root cap border cells compared to the whole root $(n=16)$. Border cell exudate was collected by dipping the root tip in $100 \mu$ l of water, while whole root exudate was collected by washing the root with $100 \mu$ l of water. Only very low amounts of DIMBOA were detected in the border cell exudate. (c) Effect of $\mathrm{Na}_{3} \mathrm{VO}_{4}$ (inhibitor of ATP-binding cassette (ABC)-type transporters) on exudation. No significant inhibition of exudation was observed after treatment with $5 \mathrm{mM}$ or $10 \mathrm{mM} \mathrm{Na}_{3} \mathrm{VO}_{4}(6<n<9)$. (d) Effect of $\mathrm{NH}_{4} \mathrm{Cl}$ (inhibitor of multidrug and toxic compound extrusion (MATE)-type transporters) on exudation. No significant inhibition of exudation was observed after treatment with $25 \mathrm{mM}, 50 \mathrm{mM}$, or $100 \mathrm{mM}$ $\mathrm{NH}_{4} \mathrm{Cl}(6<n<7)$ [89].

The impact of BXs and their metabolites is not restricted to distinct plant species, but rather it is quite general. As a corollary, universal cell structures are suggested targets. Proposed modes of action include induced $\mathrm{H}_{2} \mathrm{O}_{2}$ production leading to lignin accumulation, increased cell wall rigidity leading to reduced growth, and interaction with auxin signalling [9]. Intriguingly, Venturelli et al. [103] detected for Arabidopsis that AMP and AMPO directly inhibit histone deacetylases. The physiological 
effects of the metabolites might result from chromatin modifications that subsequently disturb gene expression patterns and will affect plant performance.

BXs have metal-chelating properties toward trivalent metal ions. (G)DI(M)BOA forms complexes with Fe (III) and can promote iron uptake as phytosiderophores. It has been shown that BX amounts in and outside of the root increase with higher iron concentrations in the media [104]. Thus, iron-complex formation with BXs will be adjusted to iron availability. Since the uptake of iron-complexes by the root is driven by the plant's demand [105], excess amounts of Fe (III) could be preserved in built-on BX-iron complex storages. Similarly, aluminium tolerance conferred by chelating complexes of DIMBOA and $\mathrm{Al}$ (III) has been proposed [106]. However, recent studies using defined maize lines and BX-free mutants could not detect a significant correlation between BXs and $\mathrm{Al}$ (III) sensitivity $[8,107,108]$.

\subsection{Insects}

The effects of BXs on insect performance are on different levels. They span from repelling to attracting, including developmental stage-specific retardation but also growth promotion, direct toxicity, and metabolic costs due to detoxification. Differences for distinct species might vary with respect to developmental stage at the insect side and age at the plant side.

\subsubsection{Chewing Insects}

Most data on the impact of BXs on insects have been gained from maize. The resistance of plants towards insects can be implemented by anti-feeding activity and interference with the larval metabolism, e.g., the inhibition of digestive enzymes. A correlation between BX concentration and the control of the European corn borer (Ostrinia nubilalis (Hübner, 1796)) was recognised early on [109]. 
Table 1. Impact of different BX families on target organisms and their effective concentrations.

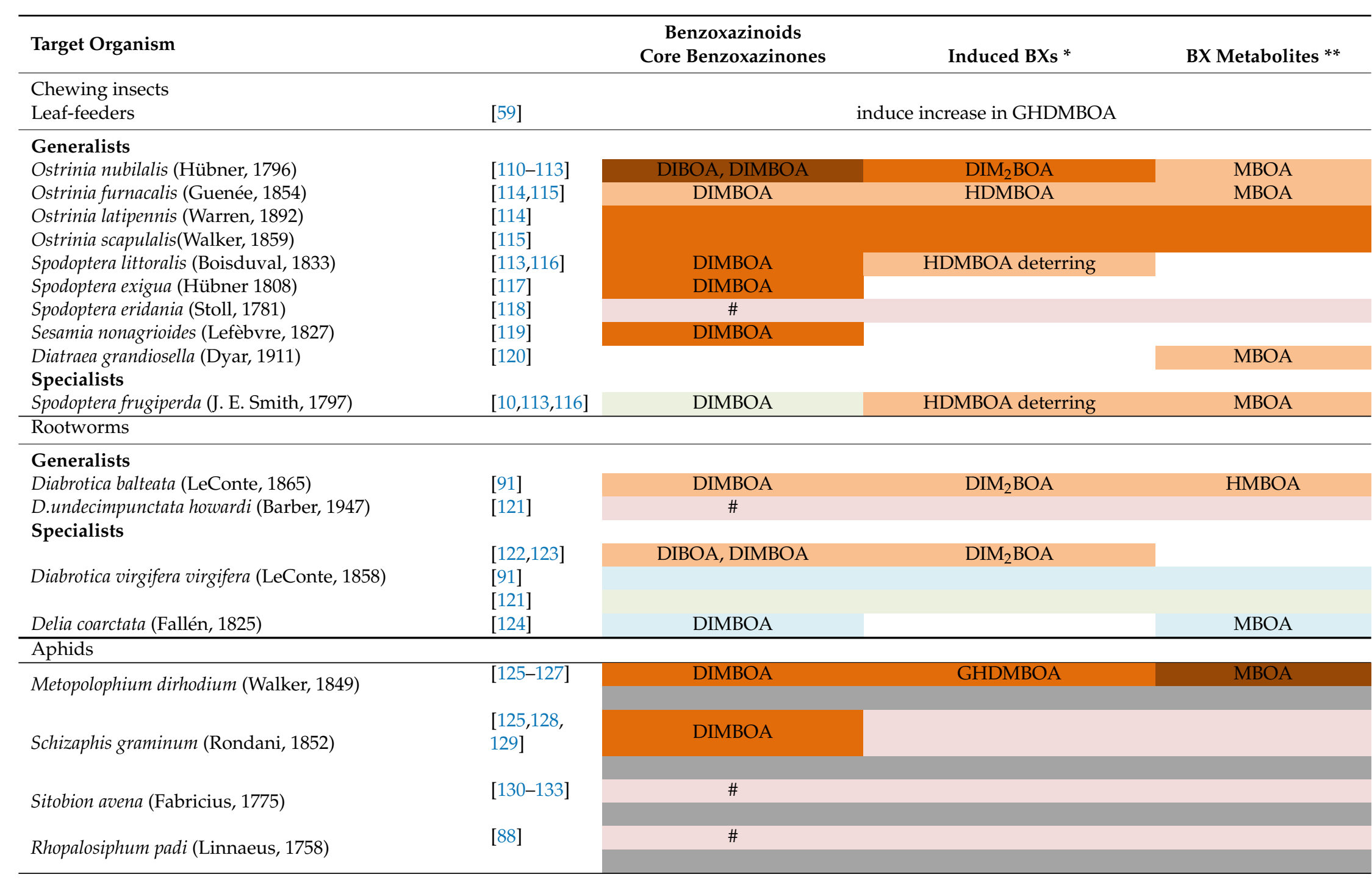


Table 1. Cont

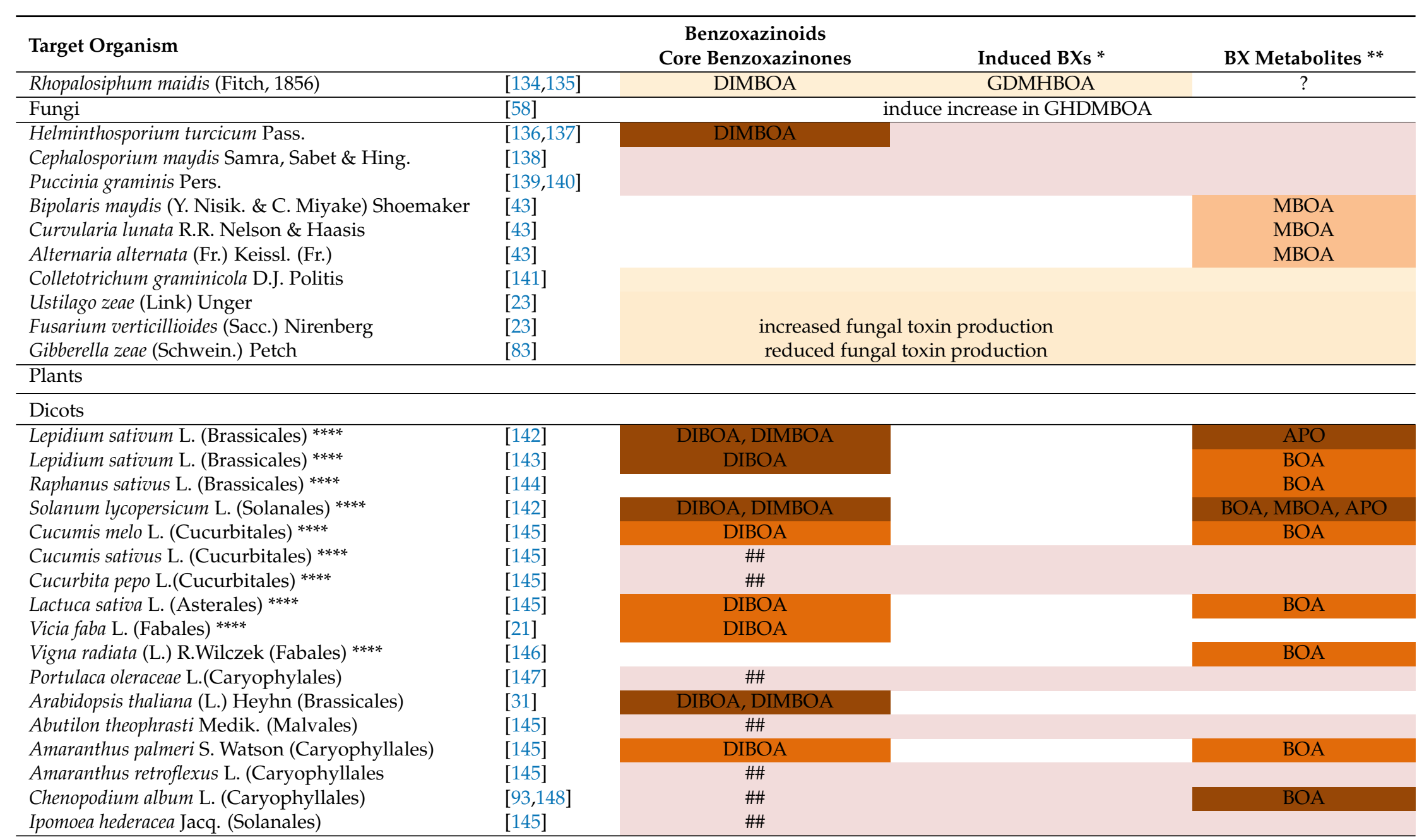


Table 1. Cont.

\begin{tabular}{|c|c|c|c|c|}
\hline \multicolumn{2}{|l|}{ Target Organism } & \multirow{2}{*}{$\begin{array}{c}\text { Benzoxazinoids } \\
\text { Core Benzoxazinones } \\
\text { \#\# }\end{array}$} & \multirow[t]{2}{*}{ Induced BXs * } & BX Metabolites ** \\
\hline Ipomoea lacunosa L. (Solanales) & {$[145]$} & & & \\
\hline Sesbania exaltata (Raf.) Rydb. (Fabales) & [145] & \#\# & & \\
\hline Senna obtusifolia (L.) H.S.Irwin \& Barneby (Fabales) & [145] & \#\# & & \\
\hline Rumex acetosa L. (Rumex acetosa) & [149] & & & BOA \\
\hline Sida spinosa L. (Malvales) & [145] & \#\# & & \\
\hline \multicolumn{5}{|l|}{ Monocots } \\
\hline Allium cepa L. (Aspargales) **** & [142] & DIBOA, DIMBOA & & $\mathrm{MBOA}, \mathrm{APO}$ \\
\hline Zea mays L. (Poales) ${ }^{* * * *}$ & [145] & DIBOA & & BOA \\
\hline Triticum aestivum L. (Poales) ${ }^{* * *}$ & [142] & DIBOA, DIMBOA & & $\mathrm{APO}$ \\
\hline Avena sativa L. (Poales) ${ }^{* * * *}$ & [21] & DIMBOA & & \\
\hline Avena fatua L. (Poales) & {$[95,150]$} & DIBOA, DIMBOA & & $\mathrm{BOA}, \mathrm{MBOA}, \mathrm{APO}$ \\
\hline Lolium rigidum Gaudin (Poales) & {$[95,150]$} & DIBOA, DIMBOA & & $\mathrm{BOA}, \mathrm{MBOA}, \mathrm{APO}$ \\
\hline Lolium perenne L. (Poales) & {$[95,150]$} & & & BOA \\
\hline Dactylis glomerata L. (Poales) & [149] & & & BOA \\
\hline Digitaria sanguinalis (L.) Scop. (Poales) & [145] & \#\# & & \\
\hline Echinochloa crus-galli (L.) P.Beauv. (Poales) & {$[143,151]$} & DIBOA, DIMBOA & & $\mathrm{APO}, \mathrm{BOA}$ \\
\hline Eleusine indica (L.) Gaertn. (Poales) & [145] & DIBOA & & BOA \\
\hline Panicum miliaceum L. (Poales) & [152] & DIBOA & & $\mathrm{BOA}$ \\
\hline
\end{tabular}

\section{Minimal concentration for negative effect}

$<1 \mathrm{mM} \quad 1-2 \mathrm{mM}$

Positive effect
Attraction
$>2 \mathrm{mM}-10 \mathrm{mM}$

Repelling

\section{$>10 \mathrm{mM} / \mathrm{not}$ affected \\ Concentration \\ spec. BX not \\ defined}


Since the BX levels are higher in seedlings and juvenile plants, mainly the first brood of the insect is affected; the control of following generations is less effective. However, fighting herbivores by pure quantity is only one strategy and is probably not conceivable for the mature plant due to high metabolic costs. Recently it has been shown that local events, including the induced biosynthesis and modification of BXs, are essential defence weapons even for juvenile plants (see $[8,153]$ for review).

Like in the case of microbial infection, peptides can be involved in the induction of BXs (ZmPep3, [59]). A major role in defence is attributed to the conversion of (G)DIMBOA to (G)HDMBOA [154]. A significant increase of (G)HDMBOA and to lesser extent (G) $\mathrm{HDM}_{2} \mathrm{BOA}$ has been shown after O. nubilalis, Ostrinia furnacalis (Guenée, 1854), Spodoptera frugiperda (J. E. Smith, 1797), S. exigua, and Spodoptera littoralis (Boisduval, 1833)caterpillar herbivory $[45,116,154-156])$. Induction takes place on gene level. Within hours, the genes $B \times 10$ and $B \times 11$ that are required for the O-methylation of GDIMBOA are upregulated, followed by an increase of core $B x$-gene transcription $[45,156]$. The activation of enzymes and transport of (G)HDMBOA might also contribute to fast local defence response. HDMBOA levels are associated with increased resistance and can be the effect of direct toxicity to the larvae or a result of the aforementioned faster conversion to MBOA compared to DIMBOA.

\subsubsection{Aphids}

Sucking insects such as aphids have both a direct and indirect influence on plant performance. Direct by the loss of energy-rich metabolites, and indirect since the transmission of viruses is often associated with sucking. The signals the plant experiences due to aphid infestation are different from those caused by the feeding of caterpillars. Preferentially, the path followed by the aphid's stylet to reach the phloem is intercellular and hence plant cell damage is minor. By contrast to findings with caterpillars, no changes in $B x$-gene transcript levels were displayed in experiments with, e.g., Rhopalosiphum padi (Linnaeus, 1758) [157].

The performance of aphids is negatively affected by BXs in wheat and wild Hordeum for Sitobion avenae (Fabricius, 1794), R. padi, and Schizaphis graminum (Rondani, 1852) [23]. Repelling in choice tests and growth effects with artificial diets are documented. Toxicity and anti-feeding symptoms in the aphids were found to be similar to starvation $[126,158]$. Recently it has been shown that the effect of BXs on aphids can be more complex than mere toxicity. The aphid's contact with BXs in the first phase of infestation is limited to some punctured mesophyll cells. It is proposed that the minimal perception of BXs experienced there extends the time to reach the phloem and has a negative effect on feeding efficiency. Since aphids feeding on maize excrete substantial amounts of BXs in the honeydew [159], uptake from the phloem sap takes place and the aphids have also to deal with the reactive compound. Species-specific differences in metabolisation and excretion might account for varying susceptibilities.

In maize and wheat for Rhopalosiphum maidis (Fitch, 1856) (corn leaf aphid) no clear correlation between BX level and aphid performance was detected. An elaborate study combining metabolomics and genetics identified an alternative BX-based resistance mechanism by elucidating the cause of natural variation in $R$. maidis resistance [44]. Resistance is conferred by the mutation of $B \times 12$, the constitutively expressed GDIMBOA O-methyltransferase. Hence, without inducing stimulus as conferred by chewing insects, GHDMBOA is missing in the plant. This finding appears contradictory since GHDMBOA is more toxic to the aphids in an artificial diet compared to GDIMBOA. However, it has been shown that DIMBOA is the required signal for the induction of callose, while HDBMOA does not affect callose concentration [88]. Since callose deposition can hinder the access to the phloem by blocking sieve elements and constricting intercellular paths, aphid performance ( $R$. maidis and probably R. padi) can be efficiently restricted by high DIMBOA levels. Hence, the activity of the core BX biosynthesis $[53,134]$ and prohibition of further metabolisation [44] increases resistance. The restriction of caterpillar damage conferred by HDMBOA and the reduction of aphid infestation depending on DIMBOA-induced callose deposition are conflicting concepts. The search for resistance to R. maidis with the background of S. exigua-mediated BX induction identified a QTL that coincides with the 
O-methyltransferase cluster $B \times 10$ to $B x 12$ [45]. The differences found in the gene expression and the resulting different GHDMBOA/GDIMBOA levels induced by caterpillar feeding affect aphid control and demonstrate that there is a trade-off between aphid and caterpillar resistance. Another factor to be considered the presence of further modifications of the $\mathrm{BX}$ structure by hydroxylation and $\mathrm{N}-\mathrm{OH}$ methylation to yield $\mathrm{GDIM}_{2} \mathrm{BOA}$ and $\mathrm{GHDM}_{2} \mathrm{BOA}$ (Figure 1, [46]). Both metabolites were shown to confer aphid control but do not contribute to resistance against chewing insects.

As mentioned before, $\mathrm{BX} 10$ to $\mathrm{BX} 12$ are equally functional in vitro as GDIMBOA O-methyltransferases to yield GHDMBOA (Figure, [46]). However, in maize the three genes displayed different expression levels. Only $B \times 12$ is expressed constitutively, while transcript levels of $B \times 10$ and $B \times 11$ were significant only upon caterpillar damage [45]. Some maize lines carry a transposon insertion in $B \times 12$ that inactivates the gene. Hence, GHDMBOA biosynthesis is restricted to caterpillar-damaged tissue in these lines. This mutant allele is present in most temperate maize lines of the 276 inbred lines of the Goodman Panel [160]. In the maize progenitor teosinte population, the allele is rare [161]. Since the threats by insects differ in tropical (chewing insects) and temperate regions (aphids), the selection of the appropriate efficient BX-GDIMBOA in case of aphids—might have been a consequence of the domestication process $[8,44-46,161]$.

\subsubsection{Specialist Insects}

Specialist insects can cope with defence metabolites and use the compounds to locate their favourite plant species. Moreover, young metabolic rich tissue is often characterised by high levels of the metabolite that is used as a cue by herbivorous insects, e.g., wheat seedling exudates attract the specialist herbivore wheat bulb fly (Delia coarctata (Fallén, 1825)). The reaction is MBOA dose-dependent; the response to DIMBOA is less pronounced [124]. Similarly, nutritious crown roots of maize are located by the corn rootworm (Diabrotica virgifera (LeConte, 1858)) by the content of BXs [91]. Moreover, D. virgifera employs BXs for its own defence [162]. MBOA and HDMBOA are used in different strategies by the insect. MBOA is $N$-glucosylated and released. The stabilised metabolite repels young nematodes that would otherwise attack the larvae. GHDMBOA is sequestered into the insect body and activated upon nematode attack. Nematodes and their symbiotic bacteria are killed by the generated high local MBOA concentrations.

Insects are exposed to the ad hoc delivery of BX aglucons following plant cell damage. Obviously instantaneous stabilisation will reduce deleterious effects. Indeed, glucosylation by UGTs in insect intestines was detected and the efficiency was correlated with the performance of the caterpillars in the presence of BXs (see [10] for review). The caterpillars excrete glucosides of DIMBOA, 2-Hydroxy-7-methoxy-1,4-benzoxazin-3-one (HMBOA), and MBOA. Interestingly the stereochemistry of the plant-derived glucoside $(2 R)$ and the insect product $(2 S)$ is different, and hence the plant $\mathrm{BX}$ glucosidase is not functional in re-activating the defence compound. Other modifications, e.g., hydroxylations, might also contribute to detoxification. The formation of GMBOA-carbamate has been revealed for Mythimna separate (Walker, 1865) [163]; however, the steric conformation differs from the respective carbamate produced by plants.

\subsection{BXs as Signalling Components}

Glucosinolates (GS) in the family Brassicaceae share features with BXs: their biosynthesis is tightly linked to tryptophan and hence auxin biosynthesis, GS are expressed constitutively at developmental stages but the pattern can be changed by biotic and abiotic stress, and both play an essential role in callose deposition $[88,164]$. Although a strong piece of evidence is lacking, it can be speculated that both specialised metabolites are recruited in parallel to serve beyond defence as signalling molecules as well. A further analogy could be the impact on flowering time. In a mapping approach with maize landraces, $B \times 12$ was identified as a locus affecting female and male flowering [165]. Similarly, GS biosynthesis has been found to influence flowering time [166]. As mentioned before, $B \times 12$ was proposed as selection target in domestication during the move from tropical to temperate regions due 
to changes in classes of challenging insects. However, the geographical spread was also obviously connected with changes in the length of day, which influences flowering time. The impact of different BX patterns on either of the two traits is not clear at present.

The background for the speculatively supposed signalling function is found in the relation to the phytohormone auxin. BXs have been described as antagonists of auxin binding and auxin-induced growth $[167,168]$ and were proposed to function contradictory as co-auxins [169]. The light-induced curvature of coleoptiles was attributed to blue light-induced $\mathrm{BX}$ accumulation and $\mathrm{H}_{2} \mathrm{O}_{2}$ released by DIMBOA production on the illuminated side [170,171]. However, the almost BX-free introgression line of the $b \times 1$ reference mutant $[13,30]$ in the maize line B73 does not show any morphological or physiological phenotype as a seedling or adult plant, under laboratory conditions, in the greenhouse, and in the field compared to B73, apart from the lack of BX [92]. This would not be expected if BX had a significant role in the auxin signalling network.

\section{Conclusions}

In defined experimental setups, the effect of BXs after damage by insects and microbes is well established. Delivered into the soil, BXs serve mutualistic interactions with geobionts. In recent years, it has become obvious that biologically active BXs constitute a compound family, comprising biosynthetic derivatives and intermediates of catabolism including microbial modifications. The amount and composition of BXs was shown to differ within species for lines and developmental stages. Furthermore, biotic and abiotic stresses influence the BX pattern. The data were mainly derived from maize, and it has yet to be evaluated how far the structural diversity and expression patterns are the same in other plants, e.g., wheat. Single BX species might be used as attractants or repellents and can be toxic. In maize, natural variation exists that might allow tailoring BXs to fit to specific requirements. However, it has to be considered that single BXs might have conflicting effects in different biotic interactions. Since the maize genes of the biosynthetic pathway are known, molecular markers can assist in selection. Mutants can clarify the impact of a given compound for plant protection.

Selectivity in the control of weeds, insects, and microbes is mediated by the different abilities of the organisms to detoxify BXs. At least for plants and insects, glycosylation seems to be the essential step to reduce deleterious effects. The long-time experience with BXs in plant protection is positive. No general breakage of resistance (e.g., by $O$. nubilalis) was observed. This might be due to the fact that diverse BXs are present that are not super toxins, i.e., killing at the lowest concentration, but that do have moderate effects on different levels in the lifecycles of the target organisms.

Although much information has been gained in recent years, much research has yet to be done to clarify the role of BXs in nature.

Author Contributions: All authors contributed to the text. The main part of the review was written by M.F.; the experimental results were contributed by C.N., and A.A. collected the bibliography. L.H. designed and drew the figures.

Funding: This work was supported by grants from the Deutsche Forschungsgemeinschaft through SFB924 and by ERA-CAPS (BENZEX) to M.F.

Acknowledgments: We would like to thank Chris-Carolin Schön for providing workspace, facilities and constant support at the Chair of Plant Breeding.

Conflicts of Interest: The authors declare no conflict of interest.

\section{References}

1. Pichersky, E.; Noel, J.P.; Dudareva, N. Biosynthesis of plant volatiles: Nature's diversity and ingenuity. Science 2006, 311, 808-811. [CrossRef] [PubMed]

2. Dixon, R.A.; Strack, D. Phytochemistry meets genome analysis, and beyond. Phytochemistry 2003, 62, 815-816. [CrossRef] 
3. Wink, M. Evolution of secondary metabolites from an ecological and molecular phylogenetic perspective. Phytochemistry 2003, 64, 3-19. [CrossRef]

4. Barry, D.; Darrah, L.L. Effect of research on commercial hybrid maize resistance to European corn borer (lepidoptera: Pyralidae). J. Econ. Entomol. 1991, 84, 1053-1059. [CrossRef]

5. Grombacher, A.W.; Russell, W.A.; Guthrie, W.D. Resistance to first-generation European corn borer (lepidoptera: Pyralidae) and DIMBOA concentration in midwhorl leaves of the BS9 maize synthetic. J. Kansas Entomol. Soc. 1989, 62, 103-107.

6. Klun, J.A.; Guthrie, W.D.; Hallauer, A.R.; Russell, W.A. Genetic nature of the concentration of 2,4-dihydroxy-7-methoxy 2h-1,4-benzoxazin-3(4h)-one and resistance to the European corn borer in a diallel set of eleven maize inbreds. Crop Sci. 1970, 10, 87-90. [CrossRef]

7. Pentzold, S.; Zagrobelny, M.; Rook, F.; Bak, S. How insects overcome two-component plant chemical defence: Plant beta-glucosidases as the main target for herbivore adaptation. Biol. Rev. 2014, 89, 531-551. [CrossRef] [PubMed]

8. Zhou, S.; Richter, A.; Jander, G. Beyond defense: Multiple functions of benzoxazinoids in maize metabolism. Plant Cell Physiol 2018. [CrossRef] [PubMed]

9. Schulz, M.; Marocco, A.; Tabaglio, V.; Macias, F.A.; Molinillo, J.M. Benzoxazinoids in rye allelopathy-From discovery to application in sustainable weed control and organic farming. J. Chem. Ecol. 2013, 39, 154-174. [CrossRef] [PubMed]

10. Wouters, F.C.; Blanchette, B.; Gershenzon, J.; Vassao, D.G. Plant defense and herbivore counter-defense: Benzoxazinoids and insect herbivores. Phytochem. Rev.: Proc. Phytochem. Soc. Eur. 2016, 15, 1127-1151. [CrossRef] [PubMed]

11. Hietala, P.K.; Virtanen, A.I. Precursors of benzoxazolinone in rye plants. II. Precursor I, the glucoside. Acta Chem. Scand. 1960, 14, 502-504. [CrossRef]

12. Pérez, F.J.; Niemeyer, H.M. Reaction of DIMBOA with amines. Phytochemistry 1989, 28, 1831-1834. [CrossRef]

13. Hamilton, R.H. A corn mutant deficient in 2,4-dihydroxy-7-methoxy-1,4-benzoxazin-3- one with an altered tolerance of atrazine. Weeds 1964, 12, 27-30. [CrossRef]

14. Wenger, K.; Bigler, L.; Suter, M.J.; Schonenberger, R.; Gupta, S.K.; Schulin, R. Effect of corn root exudates on the degradation of atrazine and its chlorinated metabolites in soils. J. Environ. Qual. 2005, 34, 2187-2196. [CrossRef] [PubMed]

15. Hashimoto, Y.; Shudo, K. Chemistry of biologically active benzoxazinoids. Phytochemistry 1996, 43, 551-559. [CrossRef]

16. Hofmann, A.; Sicker, D. A formylating agent by dehydration of the natural product dimboa. J. Nat. Prod. 1999, 62, 1151-1153. [CrossRef] [PubMed]

17. Dixon, D.P.; Sellars, J.D.; Kenwright, A.M.; Steel, P.G. The maize benzoxazinone dimboa reacts with glutathione and other thiols to form spirocyclic adducts. Phytochemistry 2012, 77, 171-178. [CrossRef] [PubMed]

18. Maresh, J.; Zhang, J.; Lynn, D.G. The innate immunity of maize and the dynamic chemical strategies regulating two-component signal transduction in agrobacterium tumefaciens. ACS Chem Biol 2006, 1, 165-175. [CrossRef] [PubMed]

19. Cuevas, L.; Niemeyer, H.M.; Pérez, F.J. Reaction of DIMBOA, a resistance factor from cereals, with $\alpha$-chymotrypsin. Phytochemistry 1990, 29, 1429-1432. [CrossRef]

20. Cuevas, L.; Niemeyer, H.M. Effect of hydroxamic acids from cereals on aphid cholinesterases. Phytochemistry 1993, 34, 983-985. [CrossRef]

21. Friebe, A.; Roth, U.; Kück, P.; Schnabl, H.; Schulz, M. Effects of 2,4-dihydroxy-1,4-benzoxazin-3-ones on the activity of plasma membrane $\mathrm{H}^{+}$-ATPase. Phytochemistry 1997, 44, 979-983. [CrossRef]

22. Sicker, D.; Frey, M.; Schulz, M.; Gierl, A. Role of natural benzoxazinones in the survival strategy of plants. Int. Rev. Cytol. 2000, 198, 319-346. [CrossRef] [PubMed]

23. Niemeyer, H.M. Hydroxamic acids derived from 2-hydroxy-2h-1,4-benzoxazin-3(4h)-one: Key defense chemicals of cereals. J. Agric. Food Chem. 2009, 57, 1677-1696. [CrossRef] [PubMed]

24. Zheng, L.; McMullen, M.D.; Bauer, E.; Schon, C.C.; Gierl, A.; Frey, M. Prolonged expression of the $b x 1$ signature enzyme is associated with a recombination hotspot in the benzoxazinoid gene cluster in Zea mays. J. Exp. Bot. 2015, 66, 3917-3930. [CrossRef] [PubMed] 
25. Yu, J.; Holland, J.B.; McMullen, M.D.; Buckler, E.S. Genetic design and statistical power of nested association mapping in maize. Genetics 2008, 178, 539. [CrossRef] [PubMed]

26. Hanhineva, K.; Rogachev, I.; Aura, A.M.; Aharoni, A.; Poutanen, K.; Mykkanen, H. Qualitative characterization of benzoxazinoid derivatives in whole grain rye and wheat by lc-ms metabolite profiling. J. Agric. Food Chem. 2011, 59, 921-927. [CrossRef] [PubMed]

27. Savolainen, O.; Pekkinen, J.; Katina, K.; Poutanen, K.; Hanhineva, K. Glycosylated benzoxazinoids are degraded during fermentation of wheat bran. J. Agric. Food Chem. 2015, 63, 5943-5949. [CrossRef] [PubMed]

28. Schullehner, K.; Dick, R.; Vitzthum, F.; Schwab, W.; Brandt, W.; Frey, M.; Gierl, A. Benzoxazinoid biosynthesis in dicot plants. Phytochemistry 2008, 69, 2668-2677. [CrossRef] [PubMed]

29. Bravo, H.R.; Copaja, S.V. Contents and morphological distribution of 2,4-dihydroxy-1,4-benzoxazin-3-one and 2-benzoxazolinone in Acanthus mollis in relation to protection from larvae of Pseudaletia impuncta. Ann. Appl. Biol. 2002, 140, 129-132. [CrossRef]

30. Frey, M.; Chomet, P.; Glawischnig, E.; Stettner, C.; Grun, S.; Winklmair, A.; Eisenreich, W.; Bacher, A.; Meeley, R.B.; Briggs, S.P.; et al. Analysis of a chemical plant defense mechanism in grasses. Science 1997, 277, 696-699. [CrossRef] [PubMed]

31. Von Rad, U.; Huttl, R.; Lottspeich, F.; Gierl, A.; Frey, M. Two glucosyltransferases are involved in detoxification of benzoxazinoids in maize. Plant J. 2001, 28, 633-642. [CrossRef] [PubMed]

32. Jonczyk, R.; Schmidt, H.; Osterrieder, A.; Fiesselmann, A.; Schullehner, K.; Haslbeck, M.; Sicker, D.; Hofmann, D.; Yalpani, N.; Simmons, C.; et al. Elucidation of the final reactions of DIMBOA-glucoside biosynthesis in maize: Characterization of $B x 6$ and Bx7. Plant Physiol. 2008, 146, 1053-1063. [CrossRef] [PubMed]

33. Nomura, T.; Ishihara, A.; Imaishi, H.; Endo, T.; Ohkawa, H.; Iwamura, H. Molecular characterization and chromosomal localization of cytochrome P450 genes involved in the biosynthesis of cyclic hydroxamic acids in hexaploid wheat. Mol. Genet. Genom. 2002, 267, 210-217. [CrossRef]

34. Nomura, T.; Ishihara, A.; Yanagita, R.C.; Endo, T.R.; Iwamura, H. Three genomes signalling differentially contribute to the biosynthesis of benzoxazinones in hexaploid wheat. Proc. Natl Acad. Sci. USA 2005, 102, 16490-16495. [CrossRef] [PubMed]

35. Nomura, T.; Nasuda, S.; Kawaura, K.; Ogihara, Y.; Kato, N.; Sato, F.; Kojima, T.; Toyoda, A.; Iwamura, H.; Endo, T.R. Structures of the three homoeologous loci of wheat benzoxazinone biosynthetic genes TaBx3 and TaBx4 and characterization of their promoter sequences. Theor. Appl. Genet. 2008, 116, 373-381. [CrossRef] [PubMed]

36. Sue, M.; Nakamura, C.; Nomura, T. Dispersed benzoxazinone gene cluster: Molecular characterization and chromosomal localization of glucosyltransferase and glucosidase genes in wheat and rye. Plant Physiol. 2011, 157, 985-997. [CrossRef] [PubMed]

37. Bakera, B.; Makowska, B.; Groszyk, J.; Niziolek, M.; Orczyk, W.; Bolibok-Bragoszewska, H.; Hromada-Judycka, A.; Rakoczy-Trojanowska, M. Structural characteristics of ScBx genes controlling the biosynthesis of hydroxamic acids in rye (Secale cereale L.). J. Appl. Genet. 2015, 56, 287-298. [CrossRef] [PubMed]

38. Rakoczy-Trojanowska, M.; Orczyk, W.; Krajewski, P.; Bocianowski, J.; Stochmal, A.; Kowalczyk, M. Scbx gene based association analysis of hydroxamate content in rye (Secale cereale L.). J. Appl. Genet. 2017, 58, 1-9. [CrossRef] [PubMed]

39. Tanwir, F.; Dionisio, G.; Adhikari, K.B.; Fomsgaard, I.S.; Gregersen, P.L. Biosynthesis and chemical transformation of benzoxazinoids in rye during seed germination and the identification of a rye $B x 6$-like gene. Phytochemistry 2017, 140, 95-107. [CrossRef] [PubMed]

40. Kriechbaumer, V.; Weigang, L.; Fießelmann, A.; Letzel, T.; Frey, M.; Gierl, A.; Glawischnig, E. Characterisation of the tryptophan synthase alpha subunit in maize. BMC Plant Biol. 2008, 8, 44. [CrossRef] [PubMed]

41. Hyde, C.C.; Ahmed, S.A.; Padlan, E.A.; Miles, E.W.; Davies, D.R. Three-dimensional structure of the tryptophan synthase alpha 2 beta 2 multienzyme complex from Salmonella typhimurium. J. Biol. Chem. 1988, 263, 17857-17871. [PubMed]

42. Spiteller, P.; Glawischnig, E.; Gierl, A.; Steglich, W. Studies on the biosynthesis of 2-hydroxy-1,4benzoxazin-3-one (HBOA) from 3-hydroxyindolin-2-one in Zea mays. Phytochemistry 2001, 57, 373-376. [CrossRef] 
43. Oikawa, A.; Ishihara, A.; Tanaka, C.; Mori, N.; Tsuda, M.; Iwamura, H. Accumulation of HDMBOA-glc is induced by biotic stresses prior to the release of MBOA in maize leaves. Phytochemistry 2004, 65, 2995-3001. [CrossRef] [PubMed]

44. Meihls, L.N.; Handrick, V.; Glauser, G.; Barbier, H.; Kaur, H.; Haribal, M.M.; Lipka, A.E.; Gershenzon, J.; Buckler, E.S.; Erb, M.; et al. Natural variation in maize aphid resistance is associated with 2,4-dihydroxy-7-methoxy-1,4-benzoxazin-3-one glucoside methyl- transferase activity. Plant Cell 2013, 25, 2341-2355. [CrossRef] [PubMed]

45. Tzin, V.; Hojo, Y.; Strickler, S.R.; Bartsch, L.J.; Archer, C.M.; Ahern, K.R.; Zhou, S.; Christensen, S.A.; Galis, I.; Mueller, L.A.; et al. Rapid defense responses in maize leaves induced by Spodoptera exigua caterpillar feeding. J. Exp. Bot. 2017, 68, 4709-4723. [CrossRef] [PubMed]

46. Handrick, V.; Robert, C.A.M.; Ahern, K.R.; Zhou, S.; Machado, R.A.R.; Maag, D.; Glauser, G.; Fernandez-Penny, F.E.; Chandran, J.N.; Rodgers-Melnik, E.; et al. Biosynthesis of 8-O-methylated benzoxazinoid defense compounds in maize. Plant Cell 2016, 28, 1682-1700. [CrossRef] [PubMed]

47. Frey, M.; Schullehner, K.; Dick, R.; Fiesselmann, A.; Gierl, A. Benzoxazinoid biosynthesis, a model for evolution of secondary metabolic pathways in plants. Phytochemistry 2009, 70, 1645-1651. [CrossRef] [PubMed]

48. Oka, R.; Zicola, J.; Weber, B.; Anderson, S.N.; Hodgman, C.; Gent, J.I.; Wesselink, J.J.; Springer, N.M.; Hoefsloot, H.C.J.; Turck, F.; et al. Genome-wide mapping of transcriptional enhancer candidates using DNA and chromatin features in maize. Genome Biol. 2017, 18, 137. [CrossRef] [PubMed]

49. Butron, A.; Chen, Y.C.; Rottinghaus, G.E.; McMullen, M.D. Genetic variation at Bx1 controls DIMBOA content in maize. Theor. Appl. Genet. 2010, 120, 721-734. [CrossRef] [PubMed]

50. Nutzmann, H.W.; Huang, A.; Osbourn, A. Plant metabolic clusters-From genetics to genomics. New Phytol. 2016, 211, 771-789. [CrossRef] [PubMed]

51. Medema, M.H.; Osbourn, A. Computational genomic identification and functional reconstitution of plant natural product biosynthetic pathways. Nat. Prod. Rep. 2016, 33, 951-962. [CrossRef] [PubMed]

52. Wisecaver, J.H.; Borowsky, A.T.; Tzin, V.; Jander, G.; Kliebenstein, D.J.; Rokas, A. A global coexpression network approach for connecting genes to specialized metabolic pathways in plants. Plant Cell 2017, 29, 944-959. [CrossRef] [PubMed]

53. Tzin, V.; Fernandez-Pozo, N.; Richter, A.; Schmelz, E.A.; Schoettner, M.; Schäfer, M.; Ahern, K.R.; Meihls, L.N.; Kaur, H.; Huffaker, A.; et al. Dynamic maize responses to aphid feeding are revealed by a time series of transcriptomic and metabolomic assays. Plant Physiol. 2015, 169, 1727-1743. [CrossRef] [PubMed]

54. Esen, A. Purification and partial characterization of maize (Zea mays L.) beta-glucosidase. Plant Physiol. 1992, 98, 174-182. [CrossRef] [PubMed]

55. Czjzek, M.; Cicek, M.; Zamboni, V.; Burmeister, W.P.; Bevan, D.R.; Henrissat, B.; Esen, A. Crystal structure of a monocotyledon (Maize ZmGLU1) beta-glucosidase and a model of its complex with p-nitrophenyl beta-d-thioglucoside. Biochem. J. 2001, 354, 37-46. [CrossRef] [PubMed]

56. Nikus, J.; Daniel, G.; Jonsson, L.M. Subcellular localization of beta-glucosidase in rye, maize and wheat seedlings. Physiol. Plant. 2001, 111, 466-472. [CrossRef] [PubMed]

57. Sue, M.; Yamazaki, K.; Yajima, S.; Nomura, T.; Matsukawa, T.; Iwamura, H.; Miyamoto, T. Molecular and structural characterization of hexameric beta-d-glucosidases in wheat and rye. Plant Physiol. 2006, 141, 1237-1247. [CrossRef] [PubMed]

58. Huffaker, A.; Dafoe, N.J.; Schmelz, E.A. Zmpep1, an ortholog of Arabidopsis elicitor peptide 1, regulates maize innate immunity and enhances disease resistance. Plant Physiol. 2011, 155, 1325-1338. [CrossRef] [PubMed]

59. Huffaker, A.; Pearce, G.; Veyrat, N.; Erb, M.; Turlings, T.C.J.; Sartor, R.; Shen, Z.; Briggs, S.P.; Vaughan, M.M.; Alborn, H.T.; et al. Plant elicitor peptides are conserved signals regulating direct and indirect antiherbivore defense. Proc. Nat.l Acad. Sci. 2013, 110, 5707. [CrossRef] [PubMed]

60. Oikawa, A.; Ishihara, A.; Hasegawa, M.; Kodama, O.; Iwamura, H. Induced accumulation of 2-hydroxy-4,7-dimethoxy-1,4-benzoxazin-3-one glucoside (HDMBOA-glc) in maize leaves. Phytochemistry 2001, 56, 669-675. [CrossRef]

61. Oikawa, A.; Ishihara, A.; Iwamura, H. Induction of HDMBOA-glc accumulation and DIMBOA-glc 4-O-methyltransferase by jasmonic acid in poaceous plants. Phytochemistry 2002, 61, 331-337. [CrossRef] 
62. Dick, R.; Rattei, T.; Haslbeck, M.; Schwab, W.; Gierl, A.; Frey, M. Comparative analysis of benzoxazinoid biosynthesis in monocots and dicots: Independent recruitment of stabilization and activation functions. Plant Cell 2012, 24, 915-928. [CrossRef] [PubMed]

63. Hannemann, L.; Lucaciu, C.R.; Sharma, S.; Rattei, T.; Mayer, K.F.X.; Gierl, A.; Frey, M. A promiscuous beta-glucosidase is involved in benzoxazinoid deglycosylation in Lamium galeobdolon. Phytochemistry June 2018, Paper under review.

64. Pihlava, J.M.; Kurtelius, T. Determination of benzoxazinoids in wheat and rye beers by HPLC-DAD and UPLC-QTOF MS. Food chem. 2016, 204, 400-408. [CrossRef] [PubMed]

65. Adhikari, K.B.; Tanwir, F.; Gregersen, P.L.; Steffensen, S.K.; Jensen, B.M.; Poulsen, L.K.; Nielsen, C.H.; Hoyer, S.; Borre, M.; Fomsgaard, I.S. Benzoxazinoids: Cereal phytochemicals with putative therapeutic and health-protecting properties. Mol. Nutr. Food Res. 2015, 59, 1324-1338. [CrossRef] [PubMed]

66. Hamilton, R.H.; Bandurski, R.S.; Reusch, W.H. Isolation and characterization of a cyclic hydroxamate from Zea mays. Cereal Chem. 1962, 39, 107-113.

67. Hashimoto, Y.; Shudo, K.; Okamoto, T.; Nagao, M.; Takahashi, Y.; Sugimura, T. Mutagenicities of 4-hydroxy-1,4-benzoxazinones naturally occurring in maize plants and of related compounds. Mutat. Res. 1979, 66, 191-194. [CrossRef]

68. Arroyo, E.; Chinchilla, N.; Molinillo, J.M.; Macias, F.A.; Astola, A.; Ortiz, M.; Valdivia, M.M. Aneugenic effects of benzoxazinones in cultured human cells. Mutat. Res. 2010, 695, 81-86. [CrossRef] [PubMed]

69. Buchmann, C.A.; Nersesyan, A.; Kopp, B.; Schauberger, D.; Darroudi, F.; Grummt, T.; Krupitza, G.; Kundi, M.; Schulte-Hermann, R.; Knasmueller, S. Dihydroxy-7-methoxy-1,4-benzoxazin-3-one (DIMBOA) and 2,4-dihydroxy-1,4-benzoxazin-3-one (DIBOA), two naturally occurring benzoxazinones contained in sprouts of gramineae are potent aneugens in human-derived liver cells (hepg2). Cancer Lett. 2007, 246, 290-299. [CrossRef] [PubMed]

70. Steffensen, S.K.; Pedersen, H.A.; Adhikari, K.B.; Laursen, B.B.; Jensen, C.; Hoyer, S.; Borre, M.; Pedersen, H.H.; Borre, M.; Edwards, D.; et al. Benzoxazinoids in prostate cancer patients after a rye-intensive diet: Methods and initial results. J. Agric. Food Chem. 2016, 64, 8235-8245. [CrossRef] [PubMed]

71. Whitney, N.J.; Mortimore, C.G. Effect of 6-methoxybenzoxazolinone on the growth of Xanthomonas stewartii (erw. Smith) dowson and its presence in sweet corn (Zea mays var. Saccharata bailey). Nature 1961, 189, 596. [CrossRef]

72. Corcuera, L.J.; Woodward, M.D.; Helgeson, J.P.; Kelman, A.; Upper, C.D. 2,4-dihydroxy-7-methoxy-2h-1,4benzoxazin-3(4h)-one, an inhibitor from Zea mays with differential activity against soft rotting erwinia species. Plant Physiol. 1978, 61, 791-795. [CrossRef] [PubMed]

73. Sahi, S.V.; Chilton, M.D.; Chilton, W.S. Corn metabolites affect growth and virulence of Agrobacterium tumefaciens. Proc. Natl. Acad. Sci. USA 1990, 87, 3879-3883. [CrossRef] [PubMed]

74. Rasmann, S.; Turlings, T.C. Root signals that mediate mutualistic interactions in the rhizosphere. Curr. Opin. Plant Biol. 2016, 32, 62-68. [CrossRef] [PubMed]

75. Neal, A.L.; Ahmad, S.; Gordon-Weeks, R.; Ton, J. Benzoxazinoids in root exudates of maize attract Pseudomonas putida to the rhizosphere. PLoS ONE 2012, 7, e35498. [CrossRef] [PubMed]

76. Neal, A.L.; Ton, J. Systemic defense priming by Pseudomonas putida KT2440 in maize depends on benzoxazinoid exudation from the roots. Plant Signal. Behav. 2013, 8, e22655. [CrossRef] [PubMed]

77. Virtanen, A.I.; Hietala, P.K. 2(3)-benzoxazolinone, an anti-Fusarium factor in rye seedlings. Acta Chem. Scand. 1955, 9, 1543-1544. [CrossRef]

78. Glenn, A.E.; Gold, S.E.; Bacon, C.W. Fdb1 and fdb2, Fusarium verticillioides loci necessary for detoxification of preformed antimicrobials from corn. Mol. Plant Microbe Interact. 2002, 15, 91-101. [CrossRef] [PubMed]

79. Etzerodt, T.; Maeda, K.; Nakajima, Y.; Laursen, B.; Fomsgaard, I.S.; Kimura, M. 2,4-dihydroxy-7-methoxy2h-1,4-benzoxazin-3(4h)-one (DIMBOA) inhibits trichothecene production by Fusarium graminearum through suppression of tri6 expression. Int. J. Food Microbiol. 2015, 214, 123-128. [CrossRef] [PubMed]

80. Saunders, M.; Kohn, L.M. Host-synthesized secondary compounds influence the in vitro interactions between fungal endophytes of maize. Appl. Environ. Microbiol. 2008, 74, 136-142. [CrossRef] [PubMed]

81. Glenn, A.E.; Bacon, C.W. Fdb2 encodes a member of the arylamine n-acetyltransferase family and is necessary for biotransformation of benzoxazolinones by Fusarium verticillioides. J. Appl. Microbiol. 2009, 107, 657-671. [CrossRef] [PubMed] 
82. Glenn, A.E.; Hinton, D.M.; Yates, I.E.; Bacon, C.W. Detoxification of corn antimicrobial compounds as the basis for isolating Fusarium verticillioides and some other Fusarium species from corn. Appl. Environ. Microbiol. 2001, 67, 2973-2981. [CrossRef] [PubMed]

83. Ridenour, J.B.; Bluhm, B.H. The novel fungal-specific gene fug1 has a role in pathogenicity and fumonisin biosynthesis in Fusarium verticillioides. Mol. Plant Pathol. 2017, 18, 513-528. [CrossRef] [PubMed]

84. Saunders, M.; Kohn, L.M. Evidence for alteration of fungal endophyte community assembly by host defense compounds. New Phytol. 2009, 182, 229-238. [CrossRef] [PubMed]

85. Bravo, H.R.; Lazo, W. Antialgal and antifungal activity of natural hydroxamic acids and related compounds. J. Agricl. Food Chem. 1996, 44, 1569-1571. [CrossRef]

86. Bravo, H.R.; Copaja, S.V.; Lazo, W. Antimicrobial activity of natural 2-benzoxazolinones and related derivatives. J. Agricl. Food Chem. 1997, 45, 3255-3257. [CrossRef]

87. Glensk, M.; Gajda, B.; Franiczek, R.; Krzyzanowska, B.; Biskup, I.; Wlodarczyk, M. In vitro evaluation of the antioxidant and antimicrobial activity of DIMBOA [2,4-dihydroxy-7-methoxy-2h-1,4-benzoxazin-3(4h)-one]. Nat. Prod. Res. 2016, 30, 1305-1308. [CrossRef] [PubMed]

88. Ahmad, S.; Veyrat, N.; Gordon-Weeks, R.; Zhang, Y.; Martin, J.; Smart, L.; Glauser, G.; Erb, M.; Flors, V.; Frey, M.; et al. Benzoxazinoid metabolites regulate innate immunity against aphids and fungi in maize. Plant Physiol. 2011, 157, 317-327. [CrossRef] [PubMed]

89. Niculaes, C.; Frey, M. (Technical University of Munich, Freising, Germany) Application of transport inhibitors: Surface sterilized seeds were left overnight in tubes containing $50 \mathrm{~mL}$ of the inhibitor solution in water for imbibition. The bottom of plastic containers was covered with sponges and $50 \mathrm{~mL}$ of the inhibitor solution added. The sponges were pricked with straight steel pins. On each pin an imbibed seed was mounted. Seedlings were grown in the closed containers in the dark at $28{ }^{\circ} \mathrm{C}$ for 3 days. Collection of the exudates was done by washing the roots with 1001 water. Inhibitors applied were sodium orthovanadate, potassium cyanide, sodium azide, gramicidin, ammonium chloride, verapamil, glibenclamide and nifedipine. All inhibitors were purchased from Sigma-Aldrich Germany, now Merck KGaA, Darmstadt, Germany. The maize inbred line B73 was used in the experiment. 2016

90. Cannesan, M.A.; Gangneux, C.; Lanoue, A.; Giron, D.; Laval, K.; Hawes, M.; Driouich, A.; Vicré-Gibouin, M. Association between border cell responses and localized root infection by pathogenic Aphanomyces euteiches. Ann. Bot. 2011, 108, 459-469. [CrossRef] [PubMed]

91. Robert, C.A.; Veyrat, N.; Glauser, G.; Marti, G.; Doyen, G.R.; Villard, N.; Gaillard, M.D.; Kollner, T.G.; Giron, D.; Body, M.; et al. A specialist root herbivore exploits defensive metabolites to locate nutritious tissues. Ecol. Lett. 2012, 15, 55-64. [CrossRef] [PubMed]

92. Frey, M. (Technical University of Munich, Freising, Germany). The maize inbred line B73 was crossed with the $b x 1$ mutant line. The $b x 1$ homozygous mutant was selected in the F2 progeny. After six backcross generations the homozygous $b x 1$ mutant line was selected and propagated by selfing. 2018.

93. Putnam, A.R.; DeFrank, J. Use of phytotoxic plant residues for selective weed control. Crop Prot. 1983, 2, 173-181. [CrossRef]

94. Belz, R.G.; Hurle, K. Differential exudation of two benzoxazinoids-one of the determining factors for seedling allelopathy of triticeae species. J. Agric. Food Chem. 2005, 53, 250-261. [CrossRef] [PubMed]

95. Macías, F.A.; Marín, D.; Oliveros-Bastidas, A.; Molinillo, J.M.G. Optimization of benzoxazinones as natural herbicide models by lipophilicity enhancement. J. Agric. Food Chem. 2006, 54, 9357-9365. [CrossRef] [PubMed]

96. Fomsgaard, I.S.; Spliid, N.H.; Felding, G. Leaching of pesticides through normal-tillage and low-tillage soil-a lysimeter study. I. Isoproturon. J. Environ. Sci. Heal. B 2003, 38, 1-18. [CrossRef] [PubMed]

97. Macías, F.A.; Oliveros-Bastidas, A.; Marin, D.; Castellano, D.; Simonet, A.M.; Molinillo, J.M. Degradation Studies on Benzoxazinoids. Soil Degradation Dynamics of 2,4-Dihydroxy-7-methoxy-(2H)-1,4benzoxazin-3(4H)-one (DIMBOA) and Its Degradation Products, Phytotoxic Allelochemicals from Gramineae. J. Agric. Food Chem. 2004, 52, 6402-6413. [CrossRef] [PubMed]

98. Macías, F.A.; Oliveros-Bastidas, A.; Marín, D.; Chinchilla, N.; Castellano, D.; Molinillo, J.M.G. Evidence for an allelopathic interaction between rye and wild oats. J. Agric. Food Chem. 2014, 62, 9450-9457. [CrossRef] [PubMed]

99. Sahi, S.V.; Anderson, C.E.; Chilton, W.S. The corn wound metabolite DIMBOA causes cell death in tobacco and corn. Plant Sci. 1995, 108, 31-40. [CrossRef] 
100. Baerson, S.R.; Sánchez-Moreiras, A.; Pedrol-Bonjoch, N.; Schulz, M.; Kagan, I.A.; Agarwal, A.K.; Reigosa, M.J.; Duke, S.O. Detoxification and transcriptome response in Arabidopsis seedlings exposed to the allelochemical benzoxazolin-2(3h)-one. J. Agric. Food Chem. 2005, 280, 21867-21881. [CrossRef]

101. Hofmann, D.; Knop, M.; Hao, H.; Hennig, L.; Sicker, D.; Schulz, M. Glucosides from MBOA and BOA detoxification by Zea mays and Portulaca oleracea. J. Nat. Prod. 2006, 69, 34-37. [CrossRef] [PubMed]

102. Schulz, M.; Filary, B.; Kuhn, S.; Colby, T.; Harzen, A.; Schmidt, J.; Sicker, D.; Hennig, L.; Hofmann, D.; Disko, U.; et al. Benzoxazolinone detoxification by N-glucosylation: The multi-compartment-network of Zea mays L. Plant Signal. Behav. 2016, 11, e1119962. [CrossRef] [PubMed]

103. Venturelli, S.; Belz, R.G.; Kamper, A.; Berger, A.; von Horn, K.; Wegner, A.; Bocker, A.; Zabulon, G.; Langenecker, T.; Kohlbacher, O.; et al. Plants release precursors of histone deacetylase inhibitors to suppress growth of competitors. Plant Cell 2015, 27, 3175-3189. [CrossRef] [PubMed]

104. Petho, M. Possible role of cyclic hydroxamic acids in the iron uptake by grasses. Acta Agron. Hung. 1993, 42, 203-214.

105. Petho, M. Physiological role of the cyclic hydroxamic acids. In Proceedings of the 7th Hungarian Congress on Plant Physiology, Szeged, Hungary, 24-27.06.2002; Petho M., Ed. Acta Biol.(Szeged) 2002, 46, 175-176.

106. Poschenrieder, C.; Tolra, R.P.; Barcelo, J. A role for cyclic hydroxamates in aluminium resistance in maize? J. Inorg. Biochem. 2005, 99, 1830-1836. [CrossRef] [PubMed]

107. Clark, R.T.; Famoso, A.N.; Zhao, K.; Shaff, J.E.; Craft, E.J.; Bustamante, C.D.; McCouch, S.R.; Aneshansley, D.J.; Kochian, L.V. High-throughput two-dimensional root system phenotyping platform facilitates genetic analysis of root growth and development. Plant Cell Environ. 2013, 36, 454-466. [CrossRef] [PubMed]

108. Guimaraes, C.T.; Simoes, C.C.; Pastina, M.M.; Maron, L.G.; Magalhaes, J.V.; Vasconcellos, R.C.; Guimaraes, L.J.; Lana, U.G.; Tinoco, C.F.; Noda, R.W.; et al. Genetic dissection of al tolerance qtls in the maize genome by high density snp scan. BMC Genom. 2014, 15, 153. [CrossRef] [PubMed]

109. Klun, J.A.; Tipton, C.L.; Brindley, T.A. 2,4-dihydroxy-7-methoxy-1,4-benzoxazin-3-one (DIMBOA), an active agent in the resistance of maize to the European corn borer123. J. Econ. Entomol. 1967, 60, 1529-1533. [CrossRef]

110. Köhler, A.; Maag, D.; Veyrat, N.; Glauser, G.; Wolfender, J.L.; Turlings, T.C.J.; Erb, M. Within-plant distribution of 1,4-benzoxazin-3-ones contributes to herbivore niche differentiation in maize. Plant Cell Environ. 2015, 38, 1081-1093. [CrossRef] [PubMed]

111. Barry, D.; Alfaro, D.; Darrah, L.L. Relation of European corn borer (Lepidoptera: Pyralidae) leaf-feeding resistance and DIMBOA content in maize. Environ. Entomol. 1994, 23, 177-182. [CrossRef]

112. Campos, F.; Atkinson, J.; Arnason, J.T.; Philogéne, B.J.R.; Morand, P.; Werstiuk, N.H.; Timmins, G. Toxicity and toxicokinetics of 6-methoxybenzoxazolinone (MBOA) in the european corn borer, Ostrinia nubilalis (Hübner). J. Chem. Ecol. 1988, 14, 989-1002. [CrossRef] [PubMed]

113. Campos, F.; Atkinson, J.; Arnason, J.T.; Philogène, B.J.R.; Morand, P.; Werstiuk, N.H.; Timmins, G. Toxicokinetics of 2,4-dihydroxy-7-methoxy-1,4-benzoxazin-3-one (DIMBOA) in the european corn borer, Ostrinia nubilalis (Hübner). J. Chem. Ecol. 1989, 15, 1989-2001. [CrossRef] [PubMed]

114. Maag, D.; Dalvit, C.; Thevenet, D.; Köhler, A.; Wouters, F.C.; Vassão, D.G.; Gershenzon, J.; Wolfender, J.-L.; Turlings, T.C.J.; Erb, M.; et al. 3- $\beta$-d-glucopyranosyl-6-methoxy-2-benzoxazolinone (MBOA-N-glc) is an insect detoxification product of maize 1,4-benzoxazin-3-ones. Phytochemistry 2014, 102, 97-105. [CrossRef] [PubMed]

115. Kojima, W.; Fujii, T.; Suwa, M.; Miyazawa, M.; Ishikawa, Y. Physiological adaptation of the asian corn borer Ostrinia furnacalis to chemical defenses of its host plant, maize. J. Insect Physiol. 2010, 56, 1349-1355. [CrossRef] [PubMed]

116. Yan, F.; Liang, X.; Zhu, X. The role of DIMBOA on the feeding of Asian corn borer, Ostrinia furnacalis (guenée) (Lep., Pyralidae). J. Appl. Entomol. 1999, 123, 49-53. [CrossRef]

117. Glauser, G.; Marti, G.; Villard, N.; Doyen, G.A.; Wolfender, J.L.; Turlings, T.C.J.; Erb, M. Induction and detoxification of maize 1,4-benzoxazin-3-ones by insect herbivores. Plant J. 2011, 68, 901-911. [CrossRef] [PubMed]

118. Rostás, M. The effects of 2,4-dihydroxy-7-methoxy-1,4-benzoxazin-3-one on two species of Spodoptera and the growth of Setosphaeria turcica in vitro. J. Pest Sci. 2006, 80, 35-41. [CrossRef]

119. Manuwoto, S.; Mark Scriber, J. Consumption and utilization of three maize genotypes by the southern armyworm. J. Econo. Entomol. 1982, 75, 163-167. [CrossRef] 
120. Ortego, F.; Castanera, P.; Ruiz, M. Effect of DIMBOA on growth and digestive physiology of Sesamia nonagrioides (Lepidoptera: Noctuidae) larvae. J. Insect Physiol. 1998, 44, 95-101. [CrossRef]

121. Hedin, P.A.; Davis, F.M.; Williams, W.P. 2-hydroxy-4,7-dimethoxy-1,4-benzoxazin-3-one (N-O-Me-DIMBOA), a possible toxic factor in corn to the southwestern corn borer. J. Chem. Ecol. 1993, 19, 531-542. [CrossRef] [PubMed]

122. Alouw, J.C.; Miller, N.J. Effects of benzoxazinoids on specialist and generalist Diabrotica species. J. Appl. Entomol. 2015, 139, 424-431. [CrossRef]

123. Bjostad, L.B.; Hibbard, B.E. 6-methoxy-2-benzoxazolinone: A semiochemical for host location by western corn rootworm larvae. J. Chem. Ecol. 1992, 18, 931-944. [CrossRef] [PubMed]

124. Xie, Y.S.; Arnason, J.T.; Philogène, B.J.R.; Lambert, J.D.H.; Atkinson, J.; Morand, P. Role of 2,4-dihydroxy-7-methoxy-1,4-benzoxazin-3-one (DIMBOA) in the resistance of maize to western corn rootworm, Diabrotica virgifera virgifera (Leconte) (Coleoptera: Chrysomelidae). Can. Entomol. 1990, 122, 1177-1186. [CrossRef]

125. Rogers, C.D.; Evans, K.A. Wheat bulb fly (Delia coarctata, fallen, Diptera: Anthomyiidae) larval response to hydroxamic acid constituents of host-plant root exudates. Bull. Entomol. Res. 2013, 103, 261-268. [CrossRef] [PubMed]

126. Argandoña, V.H.; Luza, J.G.; Niemeyer, H.M.; Corcuera, L.J. Role of hydroxamic acids in the resistance of cereals to aphids. Phytochemistry 1980, 19, 1665-1668. [CrossRef]

127. Cambier, V.; Hance, T.; De Hoffmann, E. Effects of 1,4-benzoxazin-3-one derivatives from maize on survival and fecundity of Metopolophium dirhodum (Walker) on artificial diet. J. Chem. Ecol. 2001, 27, 359-370. [CrossRef] [PubMed]

128. Hansen, L.M. Effect of 6-methoxybenzoxazolin-2-one (MBOA) on the reproduction rate of the grain aphid (Sitobion avenae F.). J. Agric. Food Chem. 2006, 54, 1031-1035. [CrossRef] [PubMed]

129. Argandoña, V.H.; Niemeyer, H.M.; Corcuera, L.J. Effect of content and distribution of hydroxamic acids in wheat on infestation by the aphid Schizaphis graminum. Phytochemistry 1981, 20, 673-676. [CrossRef]

130. Corcuera, L.J.; Argandoña, V.H.; Niemeyer, H.M. Effect of cyclic hydroxamic acids from cereals on aphids. In Proceedings of the Chemistry and Biology of Hydroxamic Acids-1st International Symposium, Dayton, Ohio, USA, May 1981; Kehl, H., Ed.; Karger: Basel, Switzerland, 1982; pp. 111-118.

131. Bohidar, K.; Wratten, S.D.; Niemeyer, H.M. Effects of hydroxamic acids on the resistance of wheat to the aphid Sitobion avenae. Ann. Appl. Biol. 1986, 109, 193-198. [CrossRef]

132. Leszczynski, B.; Dixon, A.F.G. Resistance of cereals to aphids: The interaction between hydroxamic acids and glutathione s-transferases in the grain aphid Sitobion avenae (F.) (Hom., Aphididae). J. Appl. Entomol. 1992, 113, 61-67. [CrossRef]

133. Leszczynski, B.; Matok, H.; Dixon, A.F.G. Resistance of cereals to aphids: The interaction between hydroxamic acids and UDP-glucose transferases in the aphid Sitobion avenue (Homoptera: Aphididae). J. Chem. Ecol. 1992, 18, 1189-1200. [CrossRef] [PubMed]

134. Niemeyer, H.M.; Pesel, E.; Franke, S.; Francke, W. Ingestion of the benzoxazinone DIMBOA from wheat plants by aphids. Phytochemistry 1989, 28, 2307-2310. [CrossRef]

135. Betsiashvili, M.; Ahern, K.R.; Jander, G. Additive effects of two quantitative trait loci that confer Rhopalosiphum maidis (corn leaf aphid) resistance in maize inbred line Mo17. J. Exp. Bot. 2015, 66, 571-578. [CrossRef] [PubMed]

136. Bing, J.W.; Guthrie, W.D.; Dicke, F.F.; Obryckp, J.J. Relation of corn leaf aphid (Homoptera: Aphididae) colonization to DIMBOA content in maize inbred lines. J. Econ. Entomol. 1990, 83, 1626-1632. [CrossRef]

137. Couture, R.M.; Routley, D.G.; Dunn, G.M. Role of cyclic hydroxamic acids in monogenic resistance of maize to Helminthosporium turcicum. Physiol. Plant Pathol. 1971, 1, 515-521. [CrossRef]

138. Long, B.J.; Dunn, G.M.; Routley, D.G. Relationship of hydroxamate concentration in maize and field reaction to Helminthosporium turcicum. Crop Sci. 1978, 18, 573-575. [CrossRef]

139. Kostandi, S.F.; Koraiem, Y.S.; Kamara, A.; Omar, M.A. Effect of phenols in host-pathogen interaction of maize (Zea mays L.). Cephalosporium maydis system. Agrochimica 1981, 367-375.

140. Elnaghy, M.A.; Shaw, M. Correlation between resistance to stem rust and the concentration of a glucoside in wheat. Nature 1966, 210, 417. [CrossRef]

141. Zheng, Y.Q.; Zhao, Y.; Dong, F.S.; Yao, J.R.; Hurle, K. Relationship of DIMBOA content in wheat seedlings and its resistance to plant pathogens. Allelopathy J. 2005, 15, 137-143. 
142. Lyons, P.C.; Nicholson, R.L. Evidence that cyclic hydroxamate concentrations are not related to resistance of corn leaves to anthracnose. Can. J. Plant Pathol. 1989, 11, 215-220. [CrossRef]

143. Macías, F.A.; Marín, D.; Oliveros-Bastidas, A.; Castellano, D.; Simonet, A.M.; Molinillo, J.M.G. Structure-activity relationships (SAR) studies of benzoxazinones, their degradation products and analogues. Phytotoxicity on standard target species (STS). J. Agric. Food Chem. 2005, 53, 538-548. [CrossRef] [PubMed]

144. Barnes, J.P.; Putnam, A.R.; Burke, B.A.; Aasen, A.J. Isolation and characterization of allelochemicals in rye herbage. Phytochemistry 1987, 26, 1385-1390. [CrossRef]

145. Chiapusio, G.; Pellissier, F.; Gallet, C. Uptake and translocation of phytochemical 2-benzoxazolinone (BOA) in radish seeds and seedlings. J. Exp. Bot. 2004, 55, 1587-1592. [CrossRef] [PubMed]

146. Burgos, N.R.; Talbert, R.E. Differential activity of allelochemicals from Secale cereale in seedling bioassays. Weed Sci. 2000, 48, 302-310. [CrossRef]

147. Singh, H.P.; Batish, D.R.; Kaur, S.; Setia, N.; Kohli, R.K. Effects of 2-benzoxazolinone on the germination, early growth and morphogenetic response of mung bean (Phaseolus aureus). Ann. Appl. Biol. 2005, 147, 267-274. [CrossRef]

148. Tabaglio, V.; Gavazzi, C.; Schulz, M.; Marocco, A. Alternative weed control using the allelopathic effect of natural benzoxazinoids from rye mulch. Agron. Sustain. Dev. 2008, 28, 397-401. [CrossRef]

149. Schulz, M.; Marocco, A.; Tabaglio, V. BOA detoxification of four summer weeds during germination and seedling growth. J. Chem. Ecol. 2012, 38, 933-946. [CrossRef] [PubMed]

150. Hussain, M.I.; Reigosa, M.J. Allelochemical stress inhibits growth, leaf water relations, PSII photochemistry, non-photochemical fluorescence quenching, and heat energy dissipation in three C3 perennial species. J. Exp. Bot. 2011, 62, 4533-4545. [CrossRef] [PubMed]

151. Macías, F.A.; Marín, D.; Oliveros-Bastidas, A.; Castellano, D.; Simonet, A.M.; Molinillo, J.M.G. Structure-activity relationship (SAR) studies of benzoxazinones, their degradation products, and analogues. Phytotoxicity on problematic weeds Avena fatua 1. and Lolium rigidum gaud. J. Agric. Food Chem. 2006, 54, 1040-1048. [CrossRef] [PubMed]

152. Macías, F.A.; Chinchilla, N.; Varela, R.M.; Oliveros-Bastidas, A.; Marín, D.; Molinillo, J.M.G. Structure-activity relationship studies of benzoxazinones and related compounds. Phytotoxicity on Echinochloa crus-galli (L.) p. Beauv. J. Agric. Food Chem. 2005, 53, 4373-4380. [CrossRef]

153. Barnes, J.P.; Putnam, A.R. Role of benzoxazinones in allelopathy by rye (Secale cereale 1.). J. Chem. Ecol. 1987, 13, 889-906. [CrossRef] [PubMed]

154. Dafoe, N.J.; Huffaker, A.; Vaughan, M.M.; Duehl, A.J.; Teal, P.E.; Schmelz, E.A. Rapidly induced chemical defenses in maize stems and their effects on short-term growth of ostrinia nubilalis. J. Chem. Ecol. 2011, 37, 984. [CrossRef] [PubMed]

155. Guo, J.; Guo, J.; He, K.; Bai, S.; Zhang, T.; Zhao, J.; Wang, Z. Physiological responses induced by Ostrinia furnacalis (Lepidoptera: Crambidae) feeding in maize and their effects on o. Furnacalis performance. J. Econ. Entomol. 2017, 110, 739-747. [CrossRef] [PubMed]

156. Maag, D.; Kohler, A.; Robert, C.A.; Frey, M.; Wolfender, J.L.; Turlings, T.C.; Glauser, G.; Erb, M. Highly localized and persistent induction of Bx1-dependent herbivore resistance factors in maize. Plant J. 2016, 88, 976-991. [CrossRef] [PubMed]

157. Song, J.; Liu, H.; Zhuang, H.; Zhao, C.; Xu, Y.; Wu, S.; Qi, J.; Li, J.; Hettenhausen, C.; Wu, J. Transcriptomics and alternative splicing analyses reveal large differences between maize lines B73 and Mo17 in response to aphid Rhopalosiphum padi infestation. Front. Plant Sci. 2017, 8. [CrossRef] [PubMed]

158. Argandoña, V.H.; Corcuera Luis, J.; Niemeyer Hermann, M.; Campbell Bruce, C. Toxicity and feeding deterrency of hydroxamic acids from gramineae in synthetic diets against the greenbug, Schizaphis graminum. Entomol. Exp. Appl. 1983, 34, 134-138. [CrossRef]

159. Givovich, A.; Morse, S.; Cerda, H.; Niemeyer, H.M.; Wratten, S.D.; Edwards, P.J. Hydroxamic acid glucosides in honeydew of aphids feeding on wheat. J. Chem. Ecol. 1992, 18, 841-846. [CrossRef] [PubMed]

160. Flint-Garcia, S.A.; Thuillet, A.C.; Yu, J.; Pressoir, G.; Romero, S.M.; Mitchell, S.E.; Doebley, J.; Kresovich, S.; Goodman, M.M.; Buckler, E.S. Maize association population: A high-resolution platform for quantitative trait locus dissection. Plant J. 2005, 44, 1054-1064. [CrossRef] [PubMed]

161. Wang, X.; Chen, Q.; Wu, Y.; Lemmon, Z.H.; Xu, G.; Huang, C.; Liang, Y.; Xu, D.; Li, D.; Doebley, J.F.; et al. Genome-wide analysis of transcriptional variability in a large maize-teosinte population. Mol. Plant 2018, 11, 443-459. [CrossRef] [PubMed] 
162. Robert, C.A.M.; Zhang, X.; Machado, R.A.R.; Schirmer, S.; Lori, M.; Mateo, P.; Erb, M.; Gershenzon, J. Sequestration and activation of plant toxins protect the western corn rootworm from enemies at multiple trophic levels. eLife 2017, 6, e29307. [CrossRef] [PubMed]

163. Sasai, H.; Ishida, M.; Murakami, K.; Tadokoro, N.; Ishihara, A.; Nishida, R.; Mori, N. Species-specific glucosylation of DIMBOA in larvae of the rice armyworm. Biosci. Biotechnol. Biochem. 2009, 73, 1333-1338. [CrossRef] [PubMed]

164. Clay, N.K.; Adio, A.M.; Denoux, C.; Jander, G.; Ausubel, F.M. Glucosinolate metabolites required for an Arabidopsis innate immune response. Science 2009, 323, 95-101. [CrossRef] [PubMed]

165. Romero Navarro, J.A.; Willcox, M.; Burgueno, J.; Romay, C.; Swarts, K.; Trachsel, S.; Preciado, E.; Terron, A.; Delgado, H.V.; Vidal, V.; et al. A study of allelic diversity underlying flowering-time adaptation in maize landraces. Nat. Genet. 2017, 49, 476-480. [CrossRef] [PubMed]

166. Jensen, L.M.; Jepsen, H.S.K.; Halkier, B.A.; Kliebenstein, D.J.; Burow, M. Natural variation in cross-talk between glucosinolates and onset of flowering in Arabidopsis. Front. Plant Sci. 2015, 6, 697. [CrossRef] [PubMed]

167. Venis, M.A.; Watson, P.J. Naturally occuring modifiers of auxin-receptor interaction in corn: Identification as benzoxazolinones. Planta 1978, 142, 103-107. [CrossRef] [PubMed]

168. Hasegawa, K.; Togo, S.; Urashima, M.; Mizutani, J.; Kosemura, S.; Yamamura, S. An auxin-inhibiting substance from light-grown maize shoots. Phytochemistry 1992, 31, 3673-3676. [CrossRef]

169. Park, W.J.; Schäfer, A.; Prinsen, E.; van Onckelen, H.; Kang, B.G.; Hertel, R. Auxin-induced elongation of short maize coleoptile segments is supported by 2,4-dihydroxy-7-methoxy-1,4-benzoxazin-3-one. Planta 2001, 213, 92-100. [CrossRef] [PubMed]

170. González, L.F.; Rojas, M.C. Role of wall peroxidases in oat growth inhibition by DIMBOA. Phytochemistry 1999, 50, 931-937. [CrossRef]

171. Jabeen, R.; Yamada, K.; Shigemori, H.; Hasegawa, T.; Hara, M.; Kuboi, T.; Hasegawa, K. Induction of B-glucosidase activity in maize coleoptiles by blue light illumination. J. Plant Physiol. 2006, 163, 538-545. [CrossRef] [PubMed] 